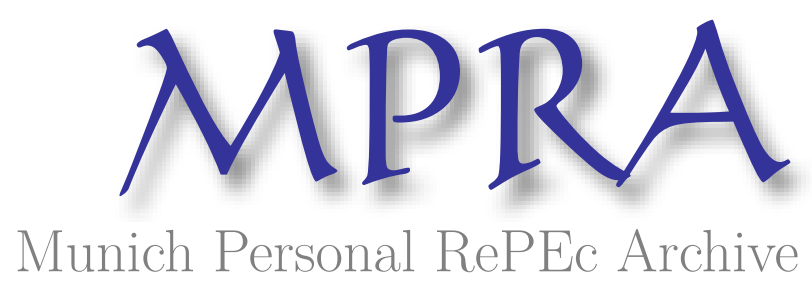

\title{
Banking Stability Determinants in Africa
}

Ozili, Peterson K

2018

Online at https://mpra.ub.uni-muenchen.de/101825/

MPRA Paper No. 101825, posted 15 Jul 2020 09:23 UTC 
Ozili P.K. (2018). Banking Stability Determinants in Africa. Forthcoming in: International Journal of Managerial Finance, Vol 14.

\title{
Banking Stability Determinants in Africa
}

\author{
Peterson K Ozili
}

2018

To cite: Ozili P.K. (2018). Banking Stability Determinants in Africa. International Journal of Managerial Finance, Vol 14. Forthcoming 
Ozili P.K. (2018). Banking Stability Determinants in Africa. Forthcoming in: International Journal of Managerial Finance, Vol 14.

Banking Stability Determinants in Africa

\begin{abstract}
This study investigates the determinants of banking stability in Africa. We present four measures of banking stability embedding banks' loan loss coverage ratio, insolvency risk, asset quality ratio, and level of financial development, thereby allowing analysis of banking stability determinants from four complementary perspectives: protection for downside credit losses, distress arising from insolvency risk, non-performing loans, and financial development. The findings indicate that banking efficiency, foreign bank presence, banking concentration, size of banking sector, government effectiveness, political stability, regulatory quality, investor protection, corruption control and unemployment levels are significant determinants of banking stability in Africa and the significance of each determinant depends on (i) the banking stability proxy employed (ii) and depends on the period of analysis: precrisis, during-crisis or post-crisis. The results highlight the importance of institutional quality for banking stability in Africa. Banking supervisors in African countries should consider the role of financial structure and institutional quality for banking stability in the African region.
\end{abstract}

JEL Code: C02, C19, C52, C61, E32, G21

Keywords: Financial Structure; Banking stability; Institutional Quality, Financial Institutions, Bank Performance. 
Ozili P.K. (2018). Banking Stability Determinants in Africa. Forthcoming in: International Journal of Managerial Finance, Vol 14.

\section{Introduction}

We investigate the determinants of banking stability in Africa. There is no agreed definition for 'banking stability' (Segoviano and Goodhart, 2009), although some policymakers like to think of banking stability as the absence of banking crises. This lack of agreement has led each national bank supervisor to decide for themselves what banking stability is, and whether banking stability includes the stability of only traditional banks or the stability of non-bank financial institutions as well as shadow banks operating outside the formal financial sector. Whatever the definition of banking stability is, an issue that is not clearly understood in the literature is the factors that influence banking stability in emerging economies, while considering the role of financial structure and institutional quality.

Frequent banking crises in African countries in the last few years have brought the fragility of African banking and finance into unprecedented focus. Often preceded, by a wave of commodity and oil import dependence by African countries coupled with exchange rate volatility, structural and institutional failures that weaken the efficacy of banks' risk management tactics (Beck and Cull, 2013), it can hardly be said that banking crises were widely foreseen. Although African banks have risk models to predict instability trends, an understanding of specific stability determinants and the variables to include in bank risk models, is important for banks operating in unpredictable environments such as Africa.

The literature has not examined banking stability determinants in Africa; therefore, this study is a comprehensive attempt to investigate the determinants of banking stability in Africa to understand why African banking systems are often unstable and susceptible to financial difficulties. In theory, bank regulators in developed economies rely mainly on capital adequacy for stability (Caprio and Honohan, 1999), and some experts believe that capital resources are insufficient to achieve banking stability in developing economies due to structural weaknesses (Brunnermeier et al 2009; Barth et al, 2004; Caprio and Honohan, 1999). Demirgüç-Kunt and Detragiache (2002) point out that regulators place much emphasis on micro-and macro-prudential regulations for banking stability but pay little attention to factors such as institutional and structural factors that bank stability while Brunnermeier et al (2009) also demonstrate that the 2008 global financial crisis and several national banking crises in countries around the world proved that crises are prone to occur in countries that have weak institutional controls and systemic dependence among banks in the financial system (Brunnermeier et al, 2009), and such interdependence can have serious consequences for banking stability. Considering these arguments, and the weak institutional environment in Africa, it is needful to identify the determinants of banking stability in Africa.

Our study differs from prior studies in that we are primarily interested in aggregate outcomes, rather than in individual bank performance, and we primarily focus on Africa. Similar to Klomp and de Haan (2012) and Fernández, González and Suárez (2016), we focus on the interaction between banking stability and institutional quality to understand the influence of institutional on banking stability in Africa. We use four measures of banking stability embedding banks' loan loss coverage ratio, insolvency risk measured as zscore, non-performing loans ratio and private credit to GDP ratio, thereby allowing analysis of banking stability determinants from four complementary perspectives: protection for downside credit losses, distress arising from insolvency risk, asset quality and financial 
Ozili P.K. (2018). Banking Stability Determinants in Africa. Forthcoming in: International Journal of Managerial Finance, Vol 14.

development levels. Our explanatory variables include bank performance variables, financial structure variables, macroeconomic variables, institutional and governance quality variables. This approach allows us to identify banking stability determinants for countries in the African region. The findings indicate that banking efficiency, foreign bank presence, banking concentration, size of banking sector, government effectiveness, political stability, investor protection, corruption control and unemployment levels have significant effects for banking stability in Africa, depending on the banking stability proxy employed and the crisis-period examined.

Our contribution to the literature is two-fold. First, our study contributes to studies in the banking literature that explore banking stability and regulation (such as Allen and Gale, 2004; Brunnermeier et al, 2009; Fernández et al, 2016; Schaeck and Cihák, 2014; Segoviano and Goodhart, 2009; Unde and Heimeshoff, 2009, etc). These studies attempt to identify the sources of fragility in the financial system, and to identify potential factors that influence stability. We add to this literature by examining the case of Africa. Studies into banking stability determinants in Africa is scant in the literature. We show that the significance of banking stability determinants in the African region depends on the banking stability proxy employed. Secondly, from a policy standpoint, insights gained from our study can help bank regulators or/and supervisors in African countries to recognize the importance of assessing not only credit loss protection and insolvency risk in the banking system, but also the impact of institutional quality, and the impact that such events and institutions would have on the stability of the banking system in the Africa.

The remainder of the article is organised as follows. Section 2 reviews the extant literature on banking stability. Section 3 presents the data and methodology. Section 4 discusses the results. Section 5 concludes.

\section{Literature Review}

Banking stability is the absence of banking crises, achieved through the stability of all banks in the banking system or sector (Brunnermeier et al, 2009). In terms of interdependence, banking stability can be defined as the stability of banks linked to each other either directly through the interbank deposits market and participations in syndicated loans, or indirectly through lending to common sectors and proprietary trades (Segoviano and Goodhart, 2009). The determinants of banking stability and its effect on financial system stability would differ across countries, therefore national bank supervisors are interested to understand banking stability determinants. The empirical literature document some economic factors, financial structure, regulation and institutional factors that influence banking stability.

\subsection{Economic Factors}

Segoviano and Goodhart (2009) show that banking instability can be caused by unexpected fluctuation in economic cycles, and the effect of booms and recessions on banking system stability will differ across countries. Jokipii and Monnin (2013) investigate the effect of real output growth and inflation on banking sector stability, using the VAR methodology approach. They use quarterly data for 18 OECD countries over the 1980 to 2008 period and observe a 
Ozili P.K. (2018). Banking Stability Determinants in Africa. Forthcoming in: International Journal of Managerial Finance, Vol 14.

positive relationship between banking sector stability and real output growth while there is no clear link between banking sector stability and inflation.

Unemployment levels is another economic determinant of bank performance. Heffernan and $\mathrm{Fu}$ (2008) examine the determinants of bank performance while controlling for unemployment levels. They predict that rising unemployment can reduce aggregate demand and increase loan default rates, hence, implying a negative relationship between unemployment levels and bank performance. Since bank performance is a major component of bank stability, high unemployment would also be positively correlated with bank instability. Heffernan and Fu (2008) examine 96 Chinese banks from the 1999 to 2006 period and find that unemployment levels have negative effects for bank performance, and hence bank stability.

Boateng et al (2015) investigate the effect of commercial bank ownership on bank performance in China. They examine 111 Chinese commercial banks over the 2000 to 2012 period. They find that foreign banks have fewer non-performing loans and overall performance although lower profitability compared to domestic banks. They also find that state-owned banks tend to be more profitable and have better liquidity position compared with other domestic banks and foreign banks. Moreover, at bank level, they observe that equity/liability ratio exerts significant influence on bank performance, while at the macroeconomic level, GDP per capital, GDP growth, inflation and unemployment rates also have significant effect on bank performance.

\subsection{Regulation and Supervision}

Barth et al. (2013) argue that banking instability may be caused by incomplete regulation or ineffective supervision although both incomplete regulation and ineffective supervision are related and cannot be examined in isolation. Incomplete regulation refers to a weak regulatory framework which gives rise to the need for regulatory reforms (US Financial Crisis Inquiry Commission, 2011), while ineffective supervision involves using weak supervisory tools, and the need to adopt the most effective supervisory tools and styles (Barth et al., 2013). Empirical evidence for the impact of strict supervision on banking stability is rather inconclusive. For instance, Delis and Staikouras (2011) and Bhattacharya et al (2002) show that strict banking supervision can limit banks' risk taking and improve the timing of supervisory intervention during periods of instability. On the other hand, Barth et al (2006, 2008) show that strict banking supervision is not associated with improvements in banking stability; and Čihàk and Tieman (2007) suggest that these mixed results are due to differences in supervision quality across countries. In other cases, regulation and supervision may have no significant effect for banking system stability. Beltratti and Stulz (2012) investigate why some banks performed better and poorly during the 2007-2008 global financial crises. Using a global sample, they find that better-performing banks had fewer leverage and lower returns before the crisis. They also observe that differences in banking regulation across countries are uncorrelated with bank performance during the crisis, except that large banks from countries with more restrictions on bank activities performed better; and the implication is that banking regulations had no effect for bank stability during the crisis.

\subsection{Institutional Factors}


Ozili P.K. (2018). Banking Stability Determinants in Africa. Forthcoming in: International Journal of Managerial Finance, Vol 14.

Some studies show that institutional quality can influence the stability of the banking system of a country (Demirguc-Kunt and Detragiache, 1997), and a country's governance quality can affect banking regulation and supervision intended to influence bank behaviour (Beltratti and Stulz, 2012; Klomp and de Haan, 2014). Klomp and de Haan (2014) examine the effect of bank regulation and supervision on bank risk. They examine 371 banks from non-industrial countries for the 2002 to 2008 period and find that strict regulation and supervision reduces bank risk, and the strength of the effect depends on the institutional quality in the domestic country. They also observe that capital regulation and supervisory controls also reduce bank riskiness while liquidity regulation and activities restriction appear to restrain banking risk only when there is a high level of institutional quality.

Fratzscher et al (2016) were concerned about how the tightening of regulation affects credit growth and the implication for bank stability. Building on the premise that strict regulation can make banks to reduce lending, they investigate 50 advanced and emerging market economies to analyse how post-crisis stringent supervision and regulation affects aggregate credit growth and subsequently banking stability. They find that higher capital buffers improved aggregate bank stability after the financial crisis, whereas a strengthening of supervisory independence helped to reduce the decline in domestic credit and improved the stability of banks. They also observe that both effects were stronger for countries with low institutional quality. The implication of the findings of Fratzscher et al (2016) is that bank supervision/regulation and institutions are substitutes rather than complements for banking stability.

\subsection{Financial Structure}

Some studies suggest that banking concentration can also influence the stability of the banking system, and there are two opposing views on the concentration-stability argument. The first argument is that banks in more concentrated markets will reduce risky lending due to lower competition in the market because they have fewer competitors (Allen and Gale 2004; Repullo, 2004). Another argument is that when the failure of a bank threatens the stability of the banking system, banks in more concentrated markets can easily reach an agreement to rescue the troubled bank to prevent wide-spread bank failure arising from contagion, hence contagion is less likely to occur in more concentrated markets (Sáez and Shi, 2004). There is also the argument that it is easier to monitor a system with only a few large banks than one with many small banks.

In contrast, some argue that banks in more concentrated markets can charge higher loan rates which can amplify the moral hazard problem on the part of borrowers inducing them to invest in more risky projects which may threaten banking system stability when losses materialise (Boyd and De Nicoló, 2005). Also, banks in concentrated markets can become too-big-to-fail, which gives rise to a moral hazard problem on the part of bank managers (Mishkin, 1999). Furthermore, the supervision of concentrated banking markets may be difficult if banks in such markets tend to be larger and more complex than their counterparts operating in less-concentrated markets (Beck et al., 2006).

Uhde and Heimeshoff (2009) observe that banking concentration has negative effects for banking stability in the European Union. They show that banking markets exhibiting low 
Ozili P.K. (2018). Banking Stability Determinants in Africa. Forthcoming in: International Journal of Managerial Finance, Vol 14.

competition, fewer diversification opportunities and a higher fraction of government-owned banks are more prone to instability whereas capital regulation has positive effects for financial stability in the EU. ljtsma, Spierdijk and Shaffer (2017) investigate the relationship between banking concentration and banking stability for the 25 European countries during the 1998 to 2014 period. They find no significant effect of banking concentration on either the bank-level or the country-level z-score, which measures bank stability. This suggest that there was no significant relationship between banking concentration and banking stability both at bank-level and country level.

Some studies suggest that competition may influence banking stability. Schaeck and Cihák (2014) examine the effect of competition on banking stability using a measure of competition based on the reallocation of profits from inefficient banks to efficient ones. They examine European banks and find that competition has positive effects from bank stability, and the positive effect is stronger for healthy banks than fragile banks. In a regional study, Liu, Molyneux and Wilson (2013) examine banks from 10 European countries over the 2000 to 2008 periods and find a non-linear relationship between bank competition and stability. They also observe that regional economic conditions play a significant role for European banking stability. Tan (2017a) examine Chinese commercial banks over the period 2003-2015 under an ordinary least square estimator. The results show that high levels of competition lead to financial fragility in the Chinese banking industry, and higher profitability positively correlate with non-performing loans of Chinese commercial banks. Tan and Floros (2014) investigates the inter-temporal relationship between banking profitability, competition and risk among Chinese commercial banks over the 2003 to 2009 period. They use the Seemingly Unrelated Regression (SUR) and find that Chinese banks with higher profitability operate in less competitive environments.

\subsection{Bank Risk}

Bank risk can have implications for banking stability. For instance, Tan and Anchor (2016) investigate the inter-relationship between profitability and stability in the Chinese banking industry. They examine 5-state-owned commercial banks, 12 joint-stock commercial banks and 83 city commercial banks over the 2003 to 2013 period. Employing the GMM approach, they find that low bank stability (higher insolvency risk) leads to higher profitability measured as ROA, and that higher profitability leads to higher bank fragility for Chinese commercial banks. Tan and Floros (2013) investigate the relationship between bank efficiency, risk and capital. They examine 101 Chinese banks over the 2003 to 2009 period and find a positive and significant relationship between risk and efficiency in Chinese banking industry, while the relationship between risk (Z-score) and bank capitalization was negatively significant.

Tan (2014) investigate bank performance, risk and competition in the Chinese banking industry. Tan use the Panzar-Rosse $\mathrm{H}$ statistic and the Lerner index to investigate competition in the Chinese banking sector over the 2003 to 2011 period, and find that the industry operates under monopolistic competition, while competition among city commercial banks is the lowest and competition among joint-stock banks is the highest. Tan further examines the impact of competition on risk-taking behaviour (credit risk and insolvency risk), and show that in a more competitive environment, Chinese commercial banks tend to undertake higher credit risk. Furthermore, Tan and Floros (2018a) test the interrelationships 
Ozili P.K. (2018). Banking Stability Determinants in Africa. Forthcoming in: International Journal of Managerial Finance, Vol 14.

among risk, competition, and efficiency in the Chinese banking industry between 2003 and 2013, using the efficiency-adjusted Lerner index and stability inefficiency as indicators of competition and insolvency risk. They show that greater competition increases liquidity risk but decreases credit risk and insolvency risk. Tan and Floros (2018b) also find similar evidence.

Tan and Anchor (2017) investigates the impact of competition on credit risk, liquidity risk, capital risk and insolvency risk in the Chinese banking industry during the period 2003-2013, and observe that greater competition within each bank ownership type (state-owned commercial banks, joint-stock commercial banks and city commercial banks) leads to higher credit risk, higher liquidity risk, higher capital risk, but lower insolvency risk, implying that competition has some positive effects for stability. Tan (2017b) find that competition leads to higher capital, liquidity and credit risk, while higher revenue efficiency leads to lower risk, while efficiency is significantly and negatively related to competition.

\subsection{Other Factors}

The literature also identify other factors influence may banking stability such as regulatory/supervisory style, deposit insurance, liquidity, bank efficiency etc. Bank efficiency is a determinant of bank performance, and bank stability. Berger and DeYoung (1997) argue that efficient banks are better at managing their credit risks because they can improve their stability by mitigating high non-performing loans. Berger and DeYoung (1997) investigate the interrelationship between bank efficiency and problem loans, a proxy for bank stability. They employ granger-causality techniques to test the relationships among loan quality, cost efficiency and bank capital. They find that higher non-performing loans precede reductions in cost efficiency, and they conclude that cost efficiency is an important indicator of future problem loans. Carretta et al (2015) investigate the supervisory styles of European bank regulators and its impact for banking stability. They examine banks from 15 European Union (EU) countries and find that supervisory culture significantly affects the stability of banks in Europe. Deposit insurance can also influence stability.

Ngalawa et al (2016) investigate the impact of moral hazard on the effectiveness of deposit insurance to achieve banking stability and find that deposit insurance has no significant effect either on banking stability or for bank runs. However, they observe that the interaction between deposit insurance with credit to the private sector has positive effects for banking stability. Liquidity levels may also influence banking stability. Wagner (2007) shows that higher levels of liquidity increases banking instability and the externalities associated with banking failures because even though higher asset liquidity directly benefits stability by encouraging banks to reduce the risks on their balance sheets and by facilitating the liquidation of assets in a crisis, it also makes crises less costly for banks because banks have an incentive to take on more risk whose negative effect is offset by the positive effect of liquidity for banking stability.

Taken together, there is substantial evidence for banking stability determinants in Europe and Asia, however, empirical evidence for banking stability determinants in Africa is scant in the banking literature, and this is our contribution to the literature. We investigate the 
Ozili P.K. (2018). Banking Stability Determinants in Africa. Forthcoming in: International Journal of Managerial Finance, Vol 14.

determinants of banking stability in Africa to identify the factors that influence African banking system stability.

\section{Data and Methodology}

\subsection{Data}

We use country data for Africa from the World Bank. We take a total sample of 48 African countries ${ }^{1}$ over the 1996 to 2015 period. Country data on banking stability and financial structure were obtained from the Global Financial Development Database (GFDD) collected by the World Bank while institutional quality data were obtained from the World Governance Indicator collected by the World bank. Some observations are missing for some years, which gives us an unbalance final sample.

\subsection{Model Specification}

We run estimations using country-level aggregate data, and regress banking stability as a function of its determinants. The baseline model specification we adopt is a modified model from Uhde and Heimeshoff (2009) and Fernández, González and Suárez (2016), and is expressed as:

Stability = f (bank-level variables, financial structure, institutional quality, macroeconomic factors)

$B S=\beta n B P E R+\beta n F I N S T R U C T+\beta n I G V+\beta n M A C R O+e$

The model is expanded as:

$$
\begin{aligned}
& B S i, t=\beta 1 N I M i, t+\beta 2 N I I i, t+\beta 3 \text { CARi } t+\beta 4 C I i, t+\beta 5 B C O N i, t+\beta 6 F G N i, t \\
& +\beta 7 \text { SIZEi }, t+\beta 8 L E R N E R i, t+\beta 9 \Delta G D P i, t+\beta 10 U N E M P i, t \\
& +\beta 11 L E G A L i, t+\beta 12 G T i, t+\beta 13 R Q i, t+\beta 14 \text { COCi, } t+\beta 15 P S i, t \\
& +e \quad \text { Equation } 1
\end{aligned}
$$

Where $\beta \mathrm{n}$ is a vector of coefficients; $\mathrm{BS}$ is the banking stability variables: insolvency risk (LnZscore), loan loss coverage ratio (LLC), non-performing loans to gross loans ratio (NPL) and standard deviation of financial development (SDFD). BPER is the bank performance variables: cost efficiency (CI), net interest margin (NIM), non-interest income (NII) and regulatory capital ratio (CAR). FINSTRUCT is the financial structure variables: competition (LERNER), bank concentration (BCON), foreign bank presence (FGN) and size of the banking

\footnotetext{
${ }^{1}$ The list of countries included in our sample are Algeria

Algeria, Angola, Botswana, Burkina Faso, Benin, Chad, Republic of Congo, Democratic Republic of Congo, Central African Republic, Cape Verde, Cameroon, Burundi, Cote d'Ivoire, Equatorial Guinea, Egypt, Djibouti, Eritrea, Ethiopia, Gabon, Ghana, Guinea, Liberia, Mali, Mauritius, Nigeria, Rwanda, Sierra Leone, South Africa, Togo, Zimbabwe, Zambia, Uganda, Tunisia, Tanzania, Swaziland, Sudan, Senegal, Seychelles, Sao Tome and Principe, Niger, Namibia, Mozambique, Mauritania, Malawi, Libya, Lesotho, Kenya and Gambia.
} 
Ozili P.K. (2018). Banking Stability Determinants in Africa. Forthcoming in: International Journal of Managerial Finance, Vol 14.

sector (SIZE). IGV is the institutional and country-governance quality variables: rule of law index (LEGAL), regulatory quality index $(R Q)$, control of corruption index $(C O C)$, political stability and absence of terrorism index (PS) and government effectiveness index (GT). MACRO variables: inflation (INF), unemployment (UNEMP) and economic growth ( $\triangle G D P$ ). Variable description is presented in Appendix A1.

\subsection{Dependent variables}

We use four proxies for banking stability: the Zscore (ZSCORE), the ratio of non-performing loans to total loans (NPL), the ratio of private credit to GDP (FD), and the ratio of loan-loss provisions to non-performing loans (LLC). The Zscore is a measure of bank insolvency risk calculated at bank level as the return on assets plus the capital-asset ratio divided by the standard deviation ${ }^{2}$ of asset returns. ZSCORE $=($ ROA + CAR $) / S D R O A$, where ROA is the rate of return on assets, CAR is the capital-asset ratio, and SD_ROA is an estimate of the standard deviation of the rate of return on assets. A high Z-score would indicate that the banks are more stable, because it is inversely related to the probability of bank insolvency, in other words, a high z-score implies lower insolvency risk or improved banking stability (Lepetit and Strobel, 2013). Moreover, because the Z-score is considered to be highly skewed, we use the natural logarithm of Z-score, which is normally distributed. Laeven and Levine (2009), Houston et al (2010), Beck et al (2013) and Fernández, González and Suárez (2016), among others, have recently used the natural logarithm of Z-score as a proxy for bank insolvency risk when measuring banking stability.

The non-performing loans to total loans ratio and the loan loss coverage ratios are two traditional measures of bank credit risk (Martínez-Peria and Schmukler, 2001; Nier and Baumann, 2006; Ozili and Outa, 2017; Fernández, González and Suárez, 2016; Ozili 2017c). Nonperforming loans to total loans ratio reflect banks' asset quality. A low non-performing loan to gross loans ratio indicates better asset quality which subsequently improves banking stability (Ozili, 2015). Loan loss coverage ratio (LLC) is measured as the ratio of loan loss provisions to non-performing loans (Caporale et al, 2015; Ozili and Outa, 2017). A higher loan loss coverage ratio should provide greater protection against loan losses which contributes to improve banking stability while a low loan loss coverage ratio would imply insufficient protection against loan losses (Ozili and Outa, 2017). We note that a too low coverage ratio may not necessarily imply the risk of under-provisioning since it could also reflect rigorous lending practices or a strong insolvency framework where collateral repossession is easy for creditors (Mesnard et al., 2016). The fourth dependent variable is the ratio of private credit to GDP measuring financial development, defined as the ratio of private credit of deposit money banks to GDP. In this study, the financial development ratio is adjusted as the standard deviation $^{3}$ of the ratio of private credit to GDP (SDFD) following the approach of Lin and Huang

\footnotetext{
${ }^{2}$ The standard deviation is measured from 1996 to 2015

${ }^{3}$ The standard deviation is measured from 1996 to 2015
} 
Ozili P.K. (2018). Banking Stability Determinants in Africa. Forthcoming in: International Journal of Managerial Finance, Vol 14.

(2014) and Fernández, González \& Suárez (2016), who used this variable as a proxy for banking stability at country level.

\subsection{Explanatory variables}

At bank level, we use four variables to control for bank-specific factors influencing banking stability: net interest margin, non-interest income, regulatory capital ratios and bank efficiency ratio. Net interest margin (NIM) measures banking sector profitability (Ozili and Uadiale, 2017; Athanasoglou et al, 2008; Ozili 2017b). Profitable banks have higher net interest margin and are more stable than less profitable banks (Dwumfour, 2017); therefore, a positive relationship between net interest margin and banking sector stability is expected.

Regulatory capital ratio (CAR) reflects the amount of risk-capital that banks have to keep for the risks they take. In theory, higher capital requirements ensure that banks have sufficient capital to absorb unexpected losses when losses materialise (Diamond and Rajan, 2000); therefore, the higher the capital requirement the higher the risk-capital banks are required to set aside to meet losses that arise from their excessive risk-taking activities (DemirgucKunt et al, 2013), which subsequently improves bank stability. Accordingly, higher regulatory capital ratios should lead to greater safety for the banking sector and should lead to greater banking stability (Besanko and Kanatas, 1996; Aiyar et al, 2015); therefore, a positive relationship between regulatory capital ratios and banking sector stability is expected.

Non-interest income (NII) measures profit diversification in the banking sector and reflects the banking sector's reliance on fee-based and non-interest source of funds as opposed to their reliance on interest income (Smith et al, 2003; Williams, 2016; Ozili 2017a). Higher noninterest income implies greater banking sector stability because banks do not have to rely solely on interest income which is considered to be unstable due to competition among banks for depositors' money (Smith et al, 2003; Williams, 2016; Ozili 2017a). A banking sector with greater reliance on non-interest source of fund should be more stable; therefore, a positive relationship between non-interest income and banking sector stability is expected. $\mathrm{Cl}$ variable is the cost to income ratio and reflects the efficiency of the banking sector. Ideally, improved cost efficiency in the banking sector would contribute to banking stability; therefore, a lower cost-to-income ratio should correlate with improved banking stability. More so, Berger and DeYoung (1997) suggest efficient banks are better at managing their credit risk. Related studies also confirm that lower cost-to-income ratio improves bank profitability when higher profitability correlates with higher stability (Olson and Zoubi, 2011; Athanasoglou et al, 2008; Pasiouras and Kosmidou, 2007).

Our financial structure variables include: the size of the banking sector (SIZE), banking competition (LERNER), foreign bank presence (FGN) and banking concentration (BCON). SIZE variable is bank deposit to GDP ratio and reflects the size of the banking sector. The bigger the banking sector, the higher the depth and/or breadth of financial intermediation in the financial system of a country. Provided that a robust systemic risk regulatory framework is in place, a large banking sector should be relatively more stable compared to a small banking sector; hence, a positive relationship between banking stability and banking sector size is expected. Moreover, a large banking sector may correlate with greater banking instability if excessive competition drives banks to take excessive risk that could materialise as losses 
Ozili P.K. (2018). Banking Stability Determinants in Africa. Forthcoming in: International Journal of Managerial Finance, Vol 14.

during bad economic times, thereby destabilising the banking system. When this is the case, a negative relationship between banking sector stability and the size of the banking sector is expected.

Lerner index is widely used as an indicator of the degree of market power for the banking sector, which measures banking competition (Beck et al., 2013). The Lerner index is defined as the difference between output prices and marginal costs (relative to prices). The Lerner index value ranges from one to zero, with higher numbers indicating greater market power and hence less competition (Tan, 2016). Lerner index represents the extent to which a bank has market power to set its price above the marginal cost (Tan, 2016). Caminal and Matutes (2002) suggest that lower competition can lead to reduced credit rationing and larger loans, which can ultimately increase the probability of bank failure, hence greater bank instability. This suggests a positive relationship between competition and stability.

Also, foreign banks' presence (FGN) can influence bank performance (Hermes and Lensink, 2004), and subsequently affect financial system stability. FGN variable is measured as the ratio of foreign banks to total banks in the country. The presence of foreign banks can introduce new technologies and new financial products and services, and also provide a wide range of financial services for users of financial services in the country (Hermes and Lensink, 2004), which together improves the breadth and depth of financial intermediation in the financial system thereby contributing to a more stable financial system ${ }^{4}$; therefore, a positive relationship between foreign bank presence and banking stability is expected.

$\mathrm{BCON}$ variable measures banking concentration and we do not have a definite prediction for the impact of banking concentration on banking stability as indicated by opposing arguments already discussed in the literature review (see, Mishkin, 1999; Allen and Gale 2004; Boyd and De Nicoló, 2005). Next, we control for institutional and country-governance quality by using the rule of law index (LEGAL) as a proxy for investor protection or institutional protection for investors and creditors, and use the regulatory quality (RQ), control of corruption (COC), political stability and absence of terrorism (PS) and government effectiveness (GT) indexes to control for governance (or institutional) quality in each African country, as used by Kaufmann et al (2011).

Finally, we control for macroeconomic factors affecting banking sector stability. Inflation (INF) is used to control for macroeconomic factors influencing banking sector stability (Jokipii and Monnin, 2013). During inflationary periods, banks are able to charge higher prices for banking (and financial services) offered to customers. Banks can benefit from higher price margins during inflationary periods to increase their profitability which contributes to greater banking stability (Jokipii and Monnin, 2013); therefore, we expect a positive relationship between banking sector stability and inflation. Unemployment (UNEMP) is another macroeconomic factor that can potentially influence banking sector stability (Boateng et al, 2015). High unemployment makes loan defaults more probable due to increased demand for loans by borrowers. Borrowers may have difficulty to repay the principal and/or the interest on the loan facility due to loss of jobs during periods of high unemployment, and the resulting default on loan repayments could contribute to banking instability. Therefore, high unemployment

\footnotetext{
${ }^{4}$ The number of foreign banks in an African country may also be viewed as a measure of the political/legal restrictions on foreign bank entry in the banking industry.
} 
Ozili P.K. (2018). Banking Stability Determinants in Africa. Forthcoming in: International Journal of Managerial Finance, Vol 14.

levels should correlate with higher banking sector instability; therefore, we expect a negative relationship between banking sector stability and unemployment. Economic growth ( $\triangle \mathrm{GDP}$ ) is another macroeconomic factor that can potentially influence banking sector stability (Laeven and Majnoni, 2003; Bikker and Metzemakers, 2005). Loan defaults tend to be lower during periods of high economic growth, which consequently has positive effects for banking sector stability (Laeven and Majnoni, 2003); therefore, we expect a positive relationship between banking sector stability and economic growth.

The estimation technique is the fixed effect regression methodology. Due to substantial missing observations, we are unable to run system-GMM estimation because the estimation breaks-down because the number of instruments is greater than the observations for a system-GMM analysis; therefore, we use the fixed-effect regression estimations throughout the paper. For robustness, we cluster the standard errors by country and year.

\section{Empirical Result}

\subsection{Correlation}

The correlation table is reported in Table 1A. The correlation table show that multicollinearity is not an issue in our model although high correlation among few institutional variables is expected as is the case in related studies like Fernández, González \& Suárez (2016) and Uhde and Heimeshoff (2009). 
Ozili P.K. (2018). Banking Stability Determinants in Africa. Forthcoming in: International Journal of Managerial Finance, Vol 14.

Table 1. Correlations - All Variables

\begin{tabular}{|c|c|c|c|c|c|c|c|c|c|c|c|c|c|c|c|c|}
\hline & $\mathrm{BCON}$ & CAR & $\mathrm{Cl}$ & $\mathrm{COC}$ & SIZE & FGN & GDP & GT & INF & LEGAL & LERNER & $\mathrm{NII}$ & NIM & PS & $\mathrm{RQ}$ & UNEMP \\
\hline $\mathrm{BCON}$ & 1.00 & & & & & & & & & & & & & & & \\
\hline \multirow[t]{2}{*}{ CAR } & -0.01 & 1.00 & & & & & & & & & & & & & & \\
\hline & 0.86 & & & & & & & & & & & & & & & \\
\hline \multirow[t]{2}{*}{$\mathrm{Cl}$} & 0.12 & -0.07 & 1.00 & & & & & & & & & & & & & \\
\hline & 0.12 & 0.34 & & & & & & & & & & & & & & \\
\hline \multirow[t]{2}{*}{$\mathrm{COC}$} & $0.24^{\star \star \star}$ & -0.12 & -0.26 & 1.00 & & & & & & & & & & & & \\
\hline & 0.00 & 0.10 & 0.00 & & & & & & & & & & & & & \\
\hline \multirow[t]{2}{*}{ SIZE } & $-0.15^{\star}$ & $-0.18^{\star \star}$ & -0.52 & $0.47^{\star \star \star}$ & 1.00 & & & & & & & & & & & \\
\hline & 0.05 & 0.02 & 0.00 & 0.00 & & & & & & & & & & & & \\
\hline \multirow[t]{2}{*}{ FGN } & $0.18^{\star \star}$ & 0.11 & 0.02 & 0.04 & -0.12 & 1.00 & & & & & & & & & & \\
\hline & 0.01 & 0.16 & 0.73 & 0.58 & 0.11 & & & & & & & & & & & \\
\hline \multirow[t]{2}{*}{ GDP } & -0.02 & -0.07 & 0.36 & $-0.14^{\star}$ & $-0.28^{\star \star \star}$ & 0.05 & 1.00 & & & & & & & & & \\
\hline & 0.78 & 0.35 & 0.00 & 0.06 & 0.00 & 0.50 & & & & & & & & & & \\
\hline \multirow[t]{2}{*}{ GT } & 0.04 & $-0.28^{\star \star \star}$ & -0.39 & $0.86^{\star \star \star}$ & $0.65^{\star \star \star}$ & -0.06 & $-0.15^{\star \star \star}$ & 1.00 & & & & & & & & \\
\hline & 0.62 & 0.00 & 0.00 & 0.00 & 0.00 & 0.44 & 0.04 & & & & & & & & & \\
\hline \multirow[t]{2}{*}{ INF } & 0.05 & 0.01 & -0.01 & $-0.28^{\star \star \star}$ & $-0.18^{\star \star}$ & -0.11 & $0.23^{\star \star \star}$ & $-0.23^{\star \star}$ & 1.00 & & & & & & & \\
\hline & 0.55 & 0.92 & 0.89 & 0.00 & 0.02 & 0.15 & 0.00 & 0.04 & & & & & & & & \\
\hline \multirow[t]{2}{*}{ LEGAL } & 0.07 & $-0.18^{\star \star}$ & -0.45 & $0.83^{\star \star \star}$ & $0.65^{\star \star \star}$ & 0.22 & $-0.18^{\star \star}$ & $0.88^{\star \star \star}$ & $-0.19^{\star \star \star}$ & 1.00 & & & & & & \\
\hline & 0.33 & 0.02 & 0.00 & 0.00 & 0.00 & 0.01 & 0.02 & 0.00 & 0.01 & & & & & & & \\
\hline \multirow[t]{2}{*}{ LERNER } & $-0.25^{\star \star \star}$ & $0.27^{\star \star \star}$ & -0.38 & -0.01 & 0.03 & 0.05 & $-0.17^{\star \star}$ & 0.05 & $-0.15^{\star}$ & 0.07 & 1.00 & & & & & \\
\hline & 0.00 & 0.00 & 0.00 & 0.89 & 0.67 & 0.48 & 0.03 & 0.55 & 0.05 & 0.35 & & & & & & \\
\hline \multirow[t]{2}{*}{ NII } & $0.21^{\star \star}$ & $0.194^{\star \star}$ & 0.33 & -0.09 & -0.02 & -0.08 & 0.09 & $-0.16^{\star \star}$ & 0.01 & $-0.162^{\star \star}$ & $-0.20^{\star \star \star}$ & 1.00 & & & & \\
\hline & 0.01 & 0.01 & 0.00 & 0.23 & 0.82 & 0.27 & 0.21 & 0.04 & 0.87 & 0.03 & 0.01 & & & & & \\
\hline \multirow[t]{2}{*}{ NIM } & 0.11 & 0.09 & 0.29 & $-0.27^{\star \star \star}$ & $-0.69^{\star \star \star}$ & 0.004 & $0.33^{\star \star \star}$ & $-0.35^{\star \star \star}$ & $0.43^{\star \star \star}$ & $-0.33^{\star \star}$ & 0.11 & -0.09 & 1.00 & & & \\
\hline & 0.18 & 0.22 & 0.00 & 0.00 & 0.00 & 0.96 & 0.00 & 0.00 & 0.00 & 0.00 & 0.17 & 0.25 & & & & \\
\hline \multirow[t]{2}{*}{ PS } & $0.19^{\star \star}$ & $-0.13^{*}$ & -0.13 & $0.71^{\star \star \star}$ & $0.32^{\star \star \star}$ & $0.48^{\star \star \star}$ & -0.06 & $0.67^{\star \star \star}$ & $-0.19^{\star \star}$ & $0.76^{\star \star \star}$ & -0.02 & 0.02 & $-0.15^{\star \star}$ & 1.00 & & \\
\hline & 0.01 & 0.09 & 0.09 & 0.00 & 0.00 & 0.00 & 0.46 & 0.00 & 0.02 & 0.00 & 0.77 & 0.75 & 0.05 & & & \\
\hline \multirow[t]{2}{*}{$R Q$} & -0.02 & $-0.20^{\star \star}$ & $-0.32^{\star \star \star}$ & $0.73^{\star \star \star}$ & $0.64^{\star \star \star}$ & 0.02 & $-0.17^{\star \star}$ & $0.86^{\star \star \star}$ & $-0.13^{\star}$ & $0.86^{\star \star \star}$ & -0.07 & -0.09 & $-0.27^{\star \star \star}$ & $0.64^{\star \star \star}$ & 1.00 & \\
\hline & 0.82 & 0.01 & 0.00 & 0.00 & 0.00 & 0.85 & 0.02 & 0.00 & 0.09 & 0.00 & 0.34 & 0.23 & 0.00 & 0.00 & & \\
\hline \multirow[t]{2}{*}{ UNEMP } & $0.34^{\star \star \star}$ & -0.02 & -0.04 & $0.29^{\star \star \star}$ & $0.26^{\star \star \star}$ & 0.02 & $-0.22^{\star \star \star}$ & $0.26^{\star \star \star}$ & $-0.15^{\star}$ & $0.14^{*}$ & $-0.33^{\star \star \star}$ & $0.16^{\text {** }}$ & $-0.39^{\star \star \star}$ & $0.32^{\star \star \star}$ & $0.24^{\star \star \star}$ & 1.00 \\
\hline & 0.00 & 0.76 & 0.63 & 0.00 & 0.00 & 0.84 & 0.00 & 0.00 & 0.05 & 0.07 & 0.00 & 0.04 & 0.00 & 0.00 & 0.00 & \\
\hline
\end{tabular}


Ozili P.K. (2018). Banking Stability Determinants in Africa. Forthcoming in: International Journal of Managerial Finance, Vol 14.

\subsection{Banking Stability Determinants}

The result is reported in Table 2. First, we analyse the determinants of banking stability without considering institutional/governance factors in Column 1 to 4 , and we subsequently incorporate the institutional/governance factors into the model in Column 5 to 8 .

The $\mathrm{Cl}$ coefficient is positively significant when we use NPL and SDFD as banking stability proxies in Column $2 \& 4$ of Table 2 and remain significant when we introduce the institutional quality variables in Column $6 \& 8$, implying that a higher cost-to-income ratio is associated with greater banking stability when we use SDFD as the banking stability proxy while a lower cost-to-income ratio is associated with fewer non-performing loans when we use NPL as the proxy for banking stability; jointly, this suggests that greater banking efficiency improves banking stability by lowering non-performing loans. This finding is consistent with the findings of Berger and DeYoung (1997), and by implication suggests that efficient African banks are better at managing their credit risk which manifests via lower NPLs, thus improving banking stability.

The BCON coefficient is positively significant when we use NPL as the banking stability proxy in Column 2 and remain significant when we introduce the institutional quality variables in Column 6. This suggests that concentrated African banking sectors experience higher nonperforming loans; hence, greater banking instability. This finding supports the argument of Boyd and De Nicoló (2005) who suggest that concentrated banking systems allow banks to charge higher loan rates which may encourage borrowers to assume greater risk; and consequently, the volume of non-performing loans may increase, and increase the probability of bank failure. Also, the finding does not support ljtsma, Spierdijk and Shaffer (2017) who found no significant relationship between banking concentration and banking stability both at bank-level and country level.

The UNEMP coefficient is negatively significant when we use NPL as the proxy for banking stability in Column 2 and remain significant when we introduce the institutional quality variables in Column 6. This implies that high unemployment is associated with fewer nonperforming loans. This finding does not support the findings of Heffernan and Fu (2008) and Boateng et al (2015) who find a negative relationship between unemployment levels and bank stability. One explanation for the conflicting result in the case of African banks could be that African banks proactively restrain from excessive lending during periods of high unemployment periods due to concerns that borrowers cannot repay loans, thus reducing the level of nonperforming loans, which consequently improves stability during periods of high unemployment.

FGN coefficient is positively significant when we use LnZSCORE and SDFD as proxies for banking stability and is negatively significant when we use NPL as the banking stability proxy. The results remain significant only for the LnZSCORE and NPL proxies when we introduce the institutional quality variables in Column $5 \& 6$. The findings indicate that African countries with greater foreign bank presence experience greater banking stability as indicated by the fewer non-performing loans ratio and higher banking solvency; thereby leading to greater banking stability. This finding supports the finding of Boateng et al (2015) who also find that 
Ozili P.K. (2018). Banking Stability Determinants in Africa. Forthcoming in: International Journal of Managerial Finance, Vol 14.

foreign banks in China have fewer non-performing loans compared to domestic banks, which by implication suggest that foreign bank presence contributes to banking sector stability.

SIZE coefficient is positively significant when we use NPL as the proxy for banking stability and remain significant when we introduce the institutional quality variables in Column 6 and implies that African countries that have large banking sectors tend to have higher nonperforming loans. This finding does not support the view that large banking sectors tend to be relatively more stable compared to a small banking sector. Rather, the finding supports Ozili (2017b) who suggest that large banking sectors correlate with greater banking instability if excessive competition drives banks to take excessive risk that could materialise as losses during bad economic times, thereby destabilising the banking system.

For the institutional/governance quality factors, $R Q$ coefficient is negatively significant in Column 3 and implies that banks in African countries with strong regulatory quality have lower loan loss coverage. One explanation for this is that a strong regulatory quality environment can make loan losses less likely by indirectly restricting banks from taking excessive risks, and as a result, African banks do not have to keep a high loan loss coverage ratio. GT coefficient is positively and negatively significant when we use LnZSCORE and NPL respectively as banking stability proxies, and implies that banks in African countries with strong government effectiveness experience higher banking solvency and fewer nonperforming loans, hence greater banking stability. PS coefficient is negatively significant when we use LnZSCORE as the banking stability proxy, indicating that political stability is negatively associated with banking solvency, and implies that African banks in politicallystable African countries tend to experience higher insolvency risk. LEGAL coefficient is negatively significant when we use SDFD as the banking stability proxy and indicates that investor protection is inversely associated with financial development. COC coefficient is positively significant when we use LnZSCORE and SDFD as banking stability proxies and indicates that corruption control is positively associated with banking solvency and financial development, and implies that banks in African countries with strong corruption control experience greater banking solvency and higher financial development levels, hence, improving stability. The LERNER, INF and CAR coefficients either report insignificant signs or conflicting signs after we incorporated the institutional quality variables into the model. Similarly, NII coefficient is negatively significant when we use LnZSCORE and SDFD as proxies for banking stability in Column $2 \& 4$ but is insignificant when we introduce the institutional quality variables in Column 6\&8. Also, NIM coefficient is insignificant and suggests that bank net interest margin has no significant effect for banking stability in Africa.

Taken together, the results indicate that banking efficiency and foreign bank presence have positive effects for banking stability in Africa while banking concentration and size of the banking sector has negative effects for banking stability in Africa. At institutional level, higher government effectiveness and stronger corruption control has positive effects for banking stability while political stability, higher regulatory quality and investor protection are inversely associated with African banking stability.

[Insert Table 2] 
Ozili P.K. (2018). Banking Stability Determinants in Africa. Forthcoming in: International Journal of Managerial Finance, Vol 14.

\subsection{Additional/Further Analyses}

\subsubsection{Pre-crisis and Post-crisis Determinants}

Next, we investigate banking stability determinants before and after the 2007/2008 global financial crisis. To do this, we divide the sample into subsamples: the pre-financial crisis period (1996-2006) and the post-financial crisis period, the results are reported in Table 3. NIM coefficient is positively significant and suggest that NIM has positive effects for banking stability both in the pre-and post-crisis period when we use SDFD as the banking stability proxy. This finding supports Ozili and Uadiale (2017); Dwumfour (2017), Athanasoglou et al (2008) and Ozili (2017b) who suggest that profitable banks tend to be more stable.

$\triangle$ GDP coefficient is also positively significant and suggest that $\triangle$ GDP has positive effects for banking stability both in the pre-and post-crisis period when we use LLC as the banking stability proxy. This finding support Laeven and Majnoni (2003) and Bikker and Metzemakers (2005) who argue that loan defaults tend to be lower during periods of high economic growth, which consequently has positive effects for banking sector stability. SIZE coefficient is positively significant and suggest that LLC has positive effects for banking stability both in the pre- and post-crisis period when we use LnZSCORE and SDFD as the banking stability proxy. The finding supports Ozili (2017b) who suggest that large banking sectors correlate with greater banking instability if excessive competition drives banks to take excessive risk that could materialise as losses during bad economic times, thereby destabilising the banking system.

For the institutional quality variables, $R Q$ coefficient is negatively significant, and suggests that $R Q$ has negative effects for bank stability both in the pre-and post-crisis period when we use SDFD as the banking stability proxy while LEGAL coefficient has negative effects for banking stability both in the pre-and post-crisis period when we use NPL as the banking stability proxy. This implies that stronger investor protection reduced rising NPLs in the precrisis and post-crisis while regulatory quality did not improve banking stability. Taken together, the results indicate that net interest margin, gross domestic product growth rate and size of banking sector have positive effect for banking stability while regulatory quality and investor protection have negative effects for banking stability in the pre- and post-crisis period.

\section{[Insert Table 3]}

\subsubsection{During-crisis Determinants}

Next, we investigate banking stability determinants during the $2007 / 2008$ global financial crisis. To do this, we use the during-crisis subsample from 2007 to 2009. The results are reported in Table 4. The result indicates that banking sector size (SIZE), foreign bank presence (FGN) and regulatory capital ratios (CAR) are positively associated with banking stability when we use SDFD as the banking stability proxy, and implies that lower net income margin, low regulatory capital ratios and higher foreign bank presence contributed to African banking instability during the global financial crisis. At institutional level, PS coefficient is negatively significant when we use LnZSCORE as the banking stability proxy and indicates that greater political stability is correlated with greater instability during the financial crisis 
Ozili P.K. (2018). Banking Stability Determinants in Africa. Forthcoming in: International Journal of Managerial Finance, Vol 14.

period. RQ coefficient is negatively significant when we use SDFD and LLC as banking stability proxies and indicates that regulatory quality is negatively correlated with financial development levels during the crisis. COC coefficient is positively significant when we use SDFD as the banking stability proxy and indicates that corruption control is positively correlated with financial development levels during the crisis. LEGAL coefficient is negatively significant when we use LnZSCORE and LLC as banking stability proxies, and further confirms that higher investor protection is associated with higher instability and lower financial development levels during the financial crisis period. Taken together, the results indicate that low net interest margin, low regulatory capital ratios and weak corruption control contributed to the instability of the African banking sector during the global financial crisis.

For all the regression results, all standard errors were adjusted using white's robust standard error correction. Further, we re-run the model using GMM dynamic estimation, but the estimator broke down because the number of instruments exceeded the number of variables, which further gives validity to the fixed effect regression methodology we adopt.

\section{Conclusion}

This study examines the determinants of banking stability in Africa. Prior studies have documented the role of systemic risk and bank-specific shocks for financial system stability with little focus on banking stability in Africa using a large sample. We examine banking stability determinants for 48 African countries over the 1996 to 2015 period. Our results indicate that banking efficiency, foreign bank presence, banking concentration, size of banking sector, government effectiveness, political stability, regulatory quality, investor protection, corruption control and unemployment levels are significant determinants of banking stability in Africa and the effect of each determinant depends on the banking stability proxy employed.

Our results have policy implications. If bank supervisors in African countries want to improve banking stability, it is important for national bank supervisors to consider the role of financial structure and institutional quality for banking stability. Moreover, our results highlight the impact of institutional quality for African banking stability as the literature has extensively shown similar evidence for other regions, even when we use multiple banking stability proxies for Africa. A fruitful direction for future research would be to investigate the impact of economic volatility and stock price volatility on banking stability in Africa. Finally, as an extension of Ozili (2018)'s study, future studies can also examine the impact of digital finance for banking stability in the African region. 
Ozili P.K. (2018). Banking Stability Determinants in Africa. Forthcoming in: International Journal of Managerial Finance, Vol 14.

\section{Reference}

Athanasoglou, P. P., Brissimis, S. N., \& Delis, M. D. (2008), "Bank-specific, industry-specific and macroeconomic determinants of bank profitability", Journal of international financial Markets, Institutions and Money, Vol.18 No. 2, pp. 121-136.

Aiyar, S., Calomiris, C. W., \& Wieladek, T. (2015), "Bank capital regulation: theory, empirics, and policy", IMF Economic Review, Vol. 63 No.4, pp. 955-983.

Allen, F., \& Gale, D. (2004), "Competition and financial stability", Journal of Money, Credit, and banking, Vol. 36 No.3, pp. 453-480.

Barth, J. R., Caprio, G., \& Levine, R. (2004), "Bank regulation and supervision: what works best?", Journal of Financial intermediation, Vol. 13 No. 2, 205-248.

Barth et al., J.R. Barth, Caprio, R., \& Levine, R. (2008), "Bank regulations are changing: for better or worse?", Comparative Economic Studies, Vol.50 No. 4, pp. 537-563.

Barth, J. R., Caprio, G., Levine, R. (2006), "Rethinking Bank Regulation", Cambridge Books, Cambridge University Press, Cambridge.

Barth, J.R., Caprio, G, \& Levine, R. (2013), "Bank regulation and supervision in 180 countries from 1999 to 2011", Journal of Financial Economic Policy, Vol 5 No 2, pp. 111-219.

Beck, T., \& Cull, R. (2013), "Banking in Africa”, Policy Research Working Paper 6684, The World Bank.

Beck, T., Demirgüç-Kunt, A., \& Levine, R. (2006), "Bank concentration, competition, and crises: First results", Journal of Banking \& Finance, Vol. 30 No. 5, pp. 1581-1603.

Beck, T., De Jonghe, 0., \& Schepens, G. (2013), "Bank competition and stability: cross-country heterogeneity", Journal of Financial Intermediation, Vol 22 No. 2, pp. 218-244.

Beltratti, A., \& Stulz, R. M. (2012), "The credit crisis around the globe: Why did some banks perform better?", Journal of Financial Economics, Vol. 105 No. 1, pp. 1-17.

Berger, A. N. \& DeYoung, R. (1997), "Problem Loans and Cost Efficiency in Commercial Banks", Journal of Banking and Finance, Vol. 21, pp. 849-870.

Besanko, D., \& Kanatas, G. (1996), "The regulation of bank capital: Do capital standards promote bank safety?", Journal of Financial Intermediation, Vol.5 No. 2, pp. 160-183.

Bhattacharya, S., Plank, M., Strobl, G., \& Zechner, J. (2002), "Bank capital regulation with random audits", Journal of Economic Dynamics and Control, Vol. 26 No. 7, pp. 1301-1321.

Bikker, J. A., \& Metzemakers, P. A. (2005), "Bank provisioning behaviour and procyclicality", Journal of International Financial Markets, Institutions and Money, Vol. 15 No. 2, pp. 141-157.

Boateng, A., Huang, W., \& Kufuor, N. K. (2015), "Commercial bank ownership and performance in China", Applied Economics, Vol. 47 No. 49, pp. 5320-5336. 
Ozili P.K. (2018). Banking Stability Determinants in Africa. Forthcoming in: International Journal of Managerial Finance, Vol 14.

Boyd, J. H., \& De Nicolo, G. (2005), "The theory of bank risk-taking and competition revisited", The Journal of Finance, Vol. 60 No. 3, pp. 1329-1343.

Brunnermeier, M. K., Crockett, A., Goodhart, C. A., Persaud, A., \& Shin, H. S. (2009), "The fundamental principles of financial regulation, Vol. 11. ICMB, International. Center for Monetary and Banking Studies. Geneva, Switzerland.

Caminal, R., \& Matutes, C. (2002), "Market power and banking failures", International Journal of Industrial Organization, Vol. 20 No. 9, pp. 1341-1361.

Caporale, G.M., Alessi, M., Di Colli, S \& Lopez, J.S. (2015), "Loan Loss Provision: Some Empirical Evidence for Italian Banks" CESifo Working Paper Series No. 5253. March 30. Available at SSRN: https://ssrn.com/abstract=2591834

Caprio, G., \& Honohan, P. (1999), "Restoring banking stability: beyond supervised capital requirements", The Journal of Economic Perspectives, Vol. 13 No. 4, pp. 43-64.

Carretta, A., Farina, V., Fiordelisi, F., Schwizer, P., \& Lopes, F. S. S. (2015), “Don't Stand So Close to $\mathrm{Me}$ : The role of supervisory style in banking stability", Journal of Banking \& Finance, Vol. 52, pp. 180-188.

Čihàk, M., \& Tieman, A., (2007), "Assessing current prudential arrangements", In: Decressin, J., Faruqee, H., Fonteyne, W. (Eds.), Integrating Europe's Financial Markets, pp. 171-198.

Delis, M. D., \& Staikouras, P. K. (2011), "Supervisory effectiveness and bank risk", Review of Finance, Vol. 15 No. 3, pp. 511-543.

Demirgüç-Kunt, A., \& Detragiache, E. (2002). Does deposit insurance increase banking system stability? An empirical investigation. Journal of monetary economics, Vol 49 No. 7, pp. 1373-1406.

Demirguc-Kunt, A., Detragiache, E., \& Merrouche, 0. (2013). Bank capital: Lessons from the financial crisis. Journal of Money, Credit and Banking, Vol. 45 No. 6, pp. 1147-1164.

Demirgüç-Kunt, A., \& Detragiache, E. (1997), "The determinants of banking crises-evidence from developing and developed countries, Vol. 106. World Bank Publications.

Diamond, D. W., \& Rajan, R. G. (2000), "A theory of bank capital", The Journal of Finance, Vol 55 No 6, pp. 2431-2465.

Dwumfour, R. A. (2017), "Explaining banking stability in Sub-Saharan Africa", Research in International Business and Finance, Vol. 41, pp. 260-279.

Fernández, A. I., González, F., \& Suárez, N. (2016), “Banking stability, competition, and economic volatility", Journal of Financial Stability, Vol. 22, pp. 101-120.

Fratzscher, M., König, P. J., \& Lambert, C. (2016), "Credit provision and banking stability after the Great Financial Crisis: The role of bank regulation and the quality of governance", Journal of International Money and Finance, Vol. 66, pp. 113-135. 
Ozili P.K. (2018). Banking Stability Determinants in Africa. Forthcoming in: International Journal of Managerial Finance, Vol 14.

Heffernan, S., \& Fu, M. (2008), "The determinants of bank performance in China" Available at SSRN: https://ssrn.com/abstract=1247713 or http://dx.doi.org/10.2139/ssrn.1247713

Hermes, N., \& Lensink, R. (2004), "Foreign bank presence, domestic bank performance and financial development", Journal of Emerging Market Finance, Vol.3 No.2, pp.207-229.

Houston, J. F., Lin, C., Lin, P., \& Ma, Y. (2010), “Creditor rights, information sharing, and bank risk taking", Journal of Financial Economics, Vol. 96 No. 3., pp. 485-512.

IJtsma, P., Spierdijk, L., \& Shaffer, S. (2017), "The concentration-stability controversy in banking: New evidence from the EU-25", Journal of Financial Stability, Vol. 33, pp. 273-284.

Jokipii, T., \& Monnin, P. (2013), "The impact of banking sector stability on the real economy", Journal of International Money and Finance, Vol. 32, pp. 1-16.

Kaufmann, D., Kraay, A., \& Mastruzzi, M. (2011), "The worldwide governance indicators: methodology and analytical issues", Hague Journal on the Rule of Law, Vol 3 No.2, 220-246.

Klomp, J., \& De Haan, J. (2012), “Banking risk and regulation: Does one size fit all?", Journal of Banking \& Finance, Vol 36 No. 12, pp. 3197-3212.

Klomp, J., \& de Haan, J. (2014), "Bank regulation, the quality of institutions, and banking risk in emerging and developing countries: an empirical analysis", Emerging Markets Finance and Trade, Vol. 50 No. 6, pp. 19-40.

Laeven, L., \& Majnoni, G. (2003), “Loan loss provisioning and economic slowdowns: too much, too late?", Journal of Financial Intermediation, Vol.12 No.2, pp. 178-197.

Laeven, L., \& Levine, R. (2009), "Bank governance, regulation and risk taking”, Journal of Financial Economics, Vol.93 No.2, pp. 259-275.

Lepetit, L., \& Strobel, F. (2013), "Bank insolvency risk and time-varying Z-score measures," Journal of International Financial Markets, Institutions and Money, Vol.25, pp. 73-87.

Liu, H., Molyneux, P., \& Wilson, J. O. (2013), “Competition and stability in European banking: a regional analysis", The Manchester School, Vol. 81 No.2, pp. 176-201.

Lin, P. C., \& Huang, H. C. (2014), "Financial sector volatility, banking market structure and exports", The World Economy, Vol. 37 No. 10, pp. 1388-1409.

Martinez Peria, M. S., \& Schmukler, S. L. (2001). Do depositors punish banks for bad behavior? Market discipline, deposit insurance, and banking crises. The journal of finance, Vol. 56 No. 3, pp. 1029-1051.

Mesnard, B., Margerit, A., Power, C., \& Magnus, M. (2016), "Non-performing loans in the Banking Union: stocktaking and challenges", Briefing EU Commission.

Mishkin, F. S. (1999), "Financial consolidation: Dangers and opportunities", Journal of Banking \& Finance, Vol 23 No.2, pp. 675-691. 
Ozili P.K. (2018). Banking Stability Determinants in Africa. Forthcoming in: International Journal of Managerial Finance, Vol 14.

Ngalawa, H., Tchana, F. T., \& Viegi, N. (2016), "Banking instability and deposit insurance: The role of moral hazard". Journal of Applied Economics, Vol. 19 No. 2, pp. 323-350.

Nier, E., \& Baumann, U. (2006), "Market discipline, disclosure and moral hazard in banking", Journal of Financial Intermediation, Vol.15 No. 3, pp. 332-361.

Olson, D., \& Zoubi, T. A. (2011), "Efficiency and bank profitability in MENA countries. Emerging markets review", Vol. 12 No. 2, pp. 94-110.

Ozili, P. K. (2015), "Loan Loss Provisioning, Income Smoothing, Signaling, Capital Management and Procyclicality: Does IFRS Matter? Empirical Evidence from Nigeria", Mediterranean Journal of Social Science Vol. 6 No. 2, pp. 224-232

Ozili, P. K., \& Outa, E. (2017), "Bank Loan Loss Provisions Research: A Review”, Borsa Istanbul Review. Vol 17, No 3, pp. 144-163.

Ozili, P. K and Uadiale (2017), "Ownership Concentration and Bank Profitability", Future Business Journal, Vol. 3 No. 2, pp. 159-171.

Ozili, P. K. (2017a), "Bank earnings management and income smoothing using commission and fee income: A European context", International Journal of Managerial Finance, Vol 13 No.4, pp. 419-439.

Ozili, P. K. (2017b), "Bank Profitability and Capital Regulation: Evidence from Listed and nonListed Banks in Africa", Journal of African Business, Vol 18 No. 2, pp. 143-168.

Ozili, P. K. (2017c), “Non-performing loans and Financial Development: New Evidence”, SSRN Working Paper.

Ozili (2018), "Impact of Digital Finance on Financial Inclusion and Stability", Borsa Istanbul Review. Forthcoming.

Pasiouras, F., \& Kosmidou, K. (2007), "Factors influencing the profitability of domestic and foreign commercial banks in the European Union", Research in International Business and Finance, Vol. 21 No. 2, pp. 222-237.

Repullo, R. (2004), “Capital requirements, market power, and risk-taking in banking”, Journal of financial Intermediation, Vol. 13 No. 2, pp. 156-182.

Sáez, L., \& Shi, X. (2004), “Liquidity pools, risk sharing, and financial contagion”, Journal of Financial Services Research, Vol. 25 No.1, pp. 5-23.

Schaeck, K., \& Cihák, M. (2014), “Competition, efficiency, and stability in banking”, Financial Management, Vol. 43 No.1, pp. 215-241.

Segoviano, M. A., \& Goodhart, C. A. E. (2009), "Banking stability measures", No. 627. International Monetary Fund. Working Paper, 04.

Smith, R., Staikouras, C., \& Wood, G. (2003), "Non-interest income and total income stability", Working Paper No. 198. Bank of England. London. 
Ozili P.K. (2018). Banking Stability Determinants in Africa. Forthcoming in: International Journal of Managerial Finance, Vol 14.

Tan, Y. (2016), "Investigating the Performance of Chinese Banks", Palgrave Macmillan UK.

Tan, Y. (2017a), "The impacts of competition and profitability on stability: evidence from the Chinese banking industry", Available at SSRN: https://ssrn.com/abstract=3063564 or http://dx.doi.org/10.2139/ssrn.3063564.

Tan, Y. (2017b), "Risk, competition and efficiency in Chinese banking: the role of interest rate liberalization", Available at SSRN: https://ssrn.com/abstract=2949045.

Tan, Y., \& Floros, C. (2014), "Risk, profitability, and competition: evidence from the Chinese banking industry", The Journal of Developing Areas, Vol. 48 No. 3, pp. 303-319.

Tan, Y., \& Anchor, J. (2017), "Does competition only impact on insolvency risk? New evidence from the Chinese banking industry", International Journal of Managerial Finance, Vol. 13 No. 3, pp. 332-354.

Tan, Y., and Anchor, J. (2016), "Stability and profitability in the Chinese banking industry: evidence from an auto-regressive-distributed linear specification", Investment Management and Financial Innovations, Vol. 13, pp. 120-128. Available at: http://eprints.hud.ac.uk/id/eprint/30307/

Tan, Y., \& Floros, C. (2013), "Risk, capital and efficiency in Chinese banking", Journal of International Financial Markets, Institutions and Money, Vol 26, pp. 378-393.

Tan, Y. (2014), "Performance, Risk and Competition in the Chinese banking industry", Oxford: Chandos Publishing.

Tan, Y., and Floros.C. (2018a), "Risk, competition and efficiency in banking: evidence from China", Global Finance Journal. 35, 223-236.

Tan, Y., and Floros, C. (2018b), "Risk, competition and cost efficiency in the Chinese banking industry", International Journal of Banking, Accounting and Finance, forthcoming; available at:

http://www.inderscience.com/info/ingeneral/forthcoming.php?jcode=IJBAAF

Uhde, A., \& Heimeshoff, U. (2009), "Consolidation in banking and financial stability in Europe: Empirical evidence", Journal of Banking \& Finance, Vol. 33 No 7, pp. 1299-1311.

US Financial Crisis Inquiry Commission, (2011), "U.S. Financial Crisis Inquiry Commission, 2011", The Financial Crisis Inquiry Report. U.S. Government Printing Office, Washington, DC.

Wagner, W. (2007), "The liquidity of bank assets and banking stability", Journal of Banking \& Finance, Vol. 31 No.1, pp. 121-139.

Williams, B. (2016), "The impact of non-interest income on bank risk in Australia", Journal of Banking \& Finance, Vol. 73, pp. 16-37. 
Ozili P.K. (2018). Banking Stability Determinants in Africa. Forthcoming in: International Journal of Managerial Finance, Vol 14.

\section{List of Tables}

\begin{tabular}{|c|c|c|c|c|c|c|c|c|}
\hline \multicolumn{9}{|c|}{ 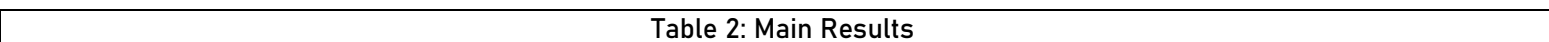 } \\
\hline \multicolumn{9}{|c|}{$\begin{array}{l}\text { Table } 2 \text { report regression results for banking stability from Column } 1 \text { to } 4 \text {. Column } 5-8 \text { includes the institutional and } \\
\text { governance variables to examine the effect of institutional quality on banking stability. The dependent variable is banking } \\
\text { stability (BS). Proxies for banking stability are the Z-score (ZSCORE), the ratio of non-performing loans to gross loans } \\
\text { (NPL), the standard deviation of private credit of deposit money banks to GDP (SDFD), and the ratio for loan loss } \\
\text { provisions to non-performing loans (LLC). In all estimations we include country and period fixed effects. Standard errors } \\
\text { are clustered by country and time. T-statistics are between parentheses. }{ }^{\star \star \star},{ }^{\star \star} \text {, and * indicate significance levels of } 1 \%, 5 \% \text {, } \\
\text { and } 10 \% \text {, respectively. }\end{array}$} \\
\hline & \multicolumn{4}{|c|}{ Banking Stability Determinants } & \multicolumn{4}{|c|}{$\begin{array}{c}\text { Banking Stability Determinants with institutional } \\
\text { quality }\end{array}$} \\
\hline & $\begin{array}{c}\text { BS: } \\
\text { LnZSCORE }\end{array}$ & BS: NPL & BS: LLC & BS: SDFD & $\begin{array}{c}\text { BS: } \\
\text { InZSCORE }\end{array}$ & BS: NPL & BS: LLC & BS: SDFD \\
\hline & $(1)$ & (2) & (3) & (4) & (1) & (2) & (3) & (4) \\
\hline & $\begin{array}{c}\text { Coefficient } \\
(t- \\
\text { statistic) }\end{array}$ & $\begin{array}{c}\text { Coefficient } \\
(t- \\
\text { statistic) }\end{array}$ & $\begin{array}{c}\text { Coefficient } \\
(t- \\
\text { statistic) }\end{array}$ & $\begin{array}{c}\text { Coefficient } \\
(t- \\
\text { statistic) }\end{array}$ & $\begin{array}{c}\text { Coefficient } \\
(t- \\
\text { statistic) }\end{array}$ & $\begin{array}{c}\text { Coefficient } \\
\text { (t- } \\
\text { statistic) }\end{array}$ & $\begin{array}{c}\text { Coefficient } \\
(\mathrm{t}- \\
\text { statistic) }\end{array}$ & $\begin{array}{c}\text { Coefficient } \\
(t- \\
\text { statistic) }\end{array}$ \\
\hline C & $\begin{array}{l}2.003^{\star \star \star} \\
(3.54)\end{array}$ & $\begin{array}{l}-14.74 \\
(-0.96)\end{array}$ & $\begin{array}{l}49.76 \\
(0.94)\end{array}$ & $\begin{array}{l}13.411^{\star \star \star} \\
(17.55)\end{array}$ & $\begin{array}{c}1.656^{\star \star \star} \\
(3.43)\end{array}$ & $\begin{array}{l}-9.127 \\
(-0.66)\end{array}$ & $\begin{array}{l}27.013 \\
(0.47)\end{array}$ & $\begin{array}{c}13.349^{\star \star \star} \\
(18.00)\end{array}$ \\
\hline NIM & $\begin{array}{l}-0.399 \\
(-0.71)\end{array}$ & $\begin{array}{l}0.268 \\
(0.42)\end{array}$ & $\begin{array}{l}-1.520 \\
(-0.94)\end{array}$ & $\begin{array}{l}-0.003 \\
(-0.13)\end{array}$ & $\begin{array}{l}-0.0002 \\
(-0.01)\end{array}$ & $\begin{array}{l}-0.163 \\
(-0.34)\end{array}$ & $\begin{array}{l}-0.781 \\
(-0.48)\end{array}$ & $\begin{array}{l}0.025 \\
(0.91)\end{array}$ \\
\hline $\mathrm{NII}$ & $\begin{array}{l}-0.009^{*} \\
(-1.65)\end{array}$ & $\begin{array}{l}0.037 \\
(0.41)\end{array}$ & $\begin{array}{l}-0.491 \\
(-1.25)\end{array}$ & $\begin{array}{c}-0.009^{\star} \\
(-1.79)\end{array}$ & $\begin{array}{l}-0.002 \\
(-0.57)\end{array}$ & $\begin{array}{l}-0.078 \\
(-1.07)\end{array}$ & $\begin{array}{l}-0.099 \\
(-0.24)\end{array}$ & $\begin{array}{l}-0.004 \\
(-0.88)\end{array}$ \\
\hline $\mathrm{Cl}$ & $\begin{array}{l}-0.003 \\
(-0.75)\end{array}$ & $\begin{array}{l}0.386^{\star \star \star} \\
(3.22)\end{array}$ & $\begin{array}{l}0.725 \\
(1.55)\end{array}$ & $\begin{array}{c}0.014^{\star \star \star} \\
(2.63)\end{array}$ & $\begin{array}{l}-0.002 \\
(-0.59)\end{array}$ & $\begin{array}{c}0.286^{\star \star} \\
(2.57)\end{array}$ & $\begin{array}{l}0.794 \\
(1.63)\end{array}$ & $\begin{array}{c}0.014^{\star \star \star} \\
(2.75)\end{array}$ \\
\hline CAR & $\begin{array}{l}0.002 \\
(0.29)\end{array}$ & $\begin{array}{l}-0.029 \\
(-0.17)\end{array}$ & $\begin{array}{l}-0.123 \\
(-0.21)\end{array}$ & $\begin{array}{l}0.009 \\
(0.87)\end{array}$ & $\begin{array}{l}-0.005 \\
(-0.63)\end{array}$ & $\begin{array}{l}0.391^{\star} \\
(1.67)\end{array}$ & $\begin{array}{l}-0.400 \\
(-0.69)\end{array}$ & $\begin{array}{l}0.003 \\
(0.32)\end{array}$ \\
\hline LERNER & $\begin{array}{l}-0.019 \\
(-0.04)\end{array}$ & $\begin{array}{l}0.249 \\
(0.03)\end{array}$ & $\begin{array}{l}14.145 \\
(0.47)\end{array}$ & $\begin{array}{l}0.281 \\
(0.68)\end{array}$ & $\begin{array}{l}-0.022 \\
(-0.05)\end{array}$ & $\begin{array}{l}-6.681 \\
(-1.08)\end{array}$ & $\begin{array}{l}12.529 \\
(0.37)\end{array}$ & $\begin{array}{c}-0.941^{\star \star} \\
(-2.43)\end{array}$ \\
\hline $\mathrm{BCON}$ & $\begin{array}{l}0.001 \\
(0.46)\end{array}$ & $\begin{array}{l}0.122^{\star} \\
(1.96)\end{array}$ & $\begin{array}{l}0.179 \\
(1.09)\end{array}$ & $\begin{array}{l}-0.001 \\
(-0.25)\end{array}$ & $\begin{array}{l}0.0003 \\
(0.13)\end{array}$ & $\begin{array}{l}0.099^{*} \\
(1.75)\end{array}$ & $\begin{array}{l}0.121 \\
(0.71)\end{array}$ & $\begin{array}{l}0.003 \\
(0.94)\end{array}$ \\
\hline FGN & $\begin{array}{c}0.010^{\star \star \star} \\
(3.76)\end{array}$ & $\begin{array}{c}-0.274^{\star \star} \\
(-2.06)\end{array}$ & $\begin{array}{l}0.067 \\
(0.19)\end{array}$ & $\begin{array}{l}0.012^{\star \star} \\
(2.41)\end{array}$ & $\begin{array}{c}0.013^{\star \star \star} \\
(3.69)\end{array}$ & $\begin{array}{c}-0.237^{\star \star \star} \\
(-2.76)\end{array}$ & $\begin{array}{l}0.339 \\
(0.89)\end{array}$ & $\begin{array}{l}0.007 \\
(1.28)\end{array}$ \\
\hline SIZE & $\begin{array}{l}0.009 \\
(1.07)\end{array}$ & $\begin{array}{c}0.486^{\star \star \star} \\
(2.71)\end{array}$ & $\begin{array}{l}-0.185 \\
(-0.20)\end{array}$ & $\begin{array}{l}-0.002 \\
(-0.25)\end{array}$ & $\begin{array}{l}0.012 \\
(1.64)\end{array}$ & $\begin{array}{c}0.503^{\star \star \star} \\
(2.67)\end{array}$ & $\begin{array}{l}-0.111 \\
(-0.12)\end{array}$ & $\begin{array}{l}-0.002 \\
(-0.24)\end{array}$ \\
\hline INF & $\begin{array}{l}-0.006 \\
(-1.19)\end{array}$ & $\begin{array}{l}0.034 \\
(0.20)\end{array}$ & $\begin{array}{l}1.390 \\
(1.42)\end{array}$ & $\begin{array}{l}-0.003 \\
(-0.31)\end{array}$ & $\begin{array}{l}-0.003 \\
(-0.73)\end{array}$ & $\begin{array}{l}0.059 \\
(0.43)\end{array}$ & $\begin{array}{c}1.456^{\star \star} \\
(1.47)\end{array}$ & $\begin{array}{l}0.011 \\
(1.19)\end{array}$ \\
\hline$\Delta \mathrm{GDP}$ & $\begin{array}{l}0.009 \\
(1.44)\end{array}$ & $\begin{array}{l}0.205 \\
(1.35)\end{array}$ & $\begin{array}{l}0.138 \\
(0.28)\end{array}$ & $\begin{array}{l}0.007 \\
(0.69)\end{array}$ & $\begin{array}{l}0.004 \\
(0.79)\end{array}$ & $\begin{array}{l}0.157 \\
(1.29)\end{array}$ & $\begin{array}{l}-0.143 \\
(-0.28)\end{array}$ & $\begin{array}{l}0.007 \\
(0.48)\end{array}$ \\
\hline UNEMP & $\begin{array}{l}0.012 \\
(0.85)\end{array}$ & $\begin{array}{c}-0.768^{*} \\
(-1.66)\end{array}$ & $\begin{array}{l}-2.203 \\
(-1.57)\end{array}$ & $\begin{array}{l}0.030 \\
(1.19)\end{array}$ & $\begin{array}{l}-0.004 \\
(-0.33)\end{array}$ & $\begin{array}{c}-1.474^{\star \star \star} \\
(-2.94)\end{array}$ & $\begin{array}{l}-2.718^{*} \\
(-1.74)\end{array}$ & $\begin{array}{l}0.004 \\
(0.15)\end{array}$ \\
\hline $\mathrm{RQ}$ & & & & & $\begin{array}{l}-0.143 \\
(-0.79)\end{array}$ & $\begin{array}{l}-1.250 \\
(-0.27)\end{array}$ & $\begin{array}{c}-32.056^{*} \\
(-1.84)\end{array}$ & $\begin{array}{l}0.437 \\
(1.38)\end{array}$ \\
\hline GT & & & & & $\begin{array}{c}0.494^{\star \star} \\
(2.45)\end{array}$ & $\begin{array}{c}-9.961^{\star *} \\
(-2.02)\end{array}$ & $\begin{array}{l}-2.063 \\
(-0.11)\end{array}$ & $\begin{array}{l}0.229 \\
(0.72)\end{array}$ \\
\hline PS & & & & & $\begin{array}{c}-0.332^{\star \star} \\
(-2.58)\end{array}$ & $\begin{array}{l}0.357 \\
(0.18)\end{array}$ & $\begin{array}{l}-6.063 \\
(-0.82)\end{array}$ & $\begin{array}{l}-0.029 \\
(-0.15)\end{array}$ \\
\hline LEGAL & & & & & $\begin{array}{l}-0.061 \\
(-0.30)\end{array}$ & $\begin{array}{c}-16.197^{\star \star} \\
(-2.27)\end{array}$ & $\begin{array}{l}11.943 \\
(0.59)\end{array}$ & $\begin{array}{c}-0.941^{\star \star} \\
(-2.43)\end{array}$ \\
\hline $\mathrm{COC}$ & & & & & $\begin{array}{l}0.291^{\star *} \\
(2.53)\end{array}$ & $\begin{array}{c}0.112 \\
(0.03)\end{array}$ & $\begin{array}{c}26.062^{\star \star} \\
(2.45)\end{array}$ & $\begin{array}{c}0.786^{\star \star \star} \\
(2.83)\end{array}$ \\
\hline $\begin{array}{c}\text { Country } \\
\text { Effect }\end{array}$ & Yes & Yes & Yes & Yes & Yes & Yes & Yes & Yes \\
\hline $\begin{array}{l}\text { Year Fixed } \\
\text { Effect }\end{array}$ & Yes & Yes & Yes & Yes & Yes & Yes & Yes & Yes \\
\hline Adjusted $\mathrm{R}^{2}$ & 88.54 & 65.71 & 38.62 & 98.93 & 90.77 & 75.26 & 38.90 & 99.12 \\
\hline F-statistic & 29.47 & 7.88 & 2.94 & 341.64 & 33.53 & 10.81 & 2.77 & 371.84 \\
\hline p-value & 0.000 & 0.000 & 0.000 & 0.000 & 0.000 & 0.000 & 0.000 & 0.000 \\
\hline Observations & 163 & 159 & 137 & 163 & 163 & 159 & 137 & 163 \\
\hline
\end{tabular}


Ozili P.K. (2018). Banking Stability Determinants in Africa. Forthcoming in: International Journal of Managerial Finance, Vol 14.

\begin{tabular}{|c|c|c|c|c|c|c|c|c|}
\hline \multicolumn{9}{|c|}{ Table 3: Pre-crisis and Post-Crisis Banking Stability Determinants } \\
\hline \multicolumn{9}{|c|}{$\begin{array}{l}\text { Table } 3 \text { show the OLS results. In all estimations, standard errors are clustered by country and year. The fixed effect } \\
\text { regression results are not significant hence we did not report it. This table shows results of regressions analysing the } \\
\text { pre-crisis determinants of banking stability from Column } 1 \text { to } 4 \text { and Column } 5-8 \text { shows results of regressions analysing the } \\
\text { post-crisis determinants of banking stability. The dependent and independent variables remain as previously defined. T- } \\
\text { statistics are between parentheses. }{ }^{\star \star \star} \text {, }{ }^{\star \star} \text {, and * indicate significance levels of } 1 \%, 5 \% \text {, and } 10 \% \text {, respectively. }\end{array}$} \\
\hline & \multicolumn{4}{|c|}{ Pre-Crisis Banking Stability Determinants } & \multicolumn{4}{|c|}{ Post-Crisis Banking Stability Determinants } \\
\hline & $\begin{array}{c}\text { BS: } \\
\text { InZscore }\end{array}$ & BS: NPL & BS: LLC & BS: SDFD & $\begin{array}{c}\text { BS: } \\
\text { InZscore }\end{array}$ & BS: NPL & BS: LLC & BS: SDFD \\
\hline & $(1)$ & (2) & (3) & (4) & $(1)$ & (2) & (3) & (4) \\
\hline & $\begin{array}{c}\text { Coefficient } \\
(t- \\
\text { statistic) }\end{array}$ & $\begin{array}{c}\text { Coefficient } \\
(t- \\
\text { statistic) }\end{array}$ & $\begin{array}{c}\text { Coefficient } \\
(t- \\
\text { statistic) }\end{array}$ & $\begin{array}{c}\text { Coefficient } \\
(\mathrm{t}- \\
\text { statistic) }\end{array}$ & $\begin{array}{c}\text { Coefficient } \\
(t- \\
\text { statistic) }\end{array}$ & $\begin{array}{c}\text { Coefficient } \\
(t- \\
\text { statistic) }\end{array}$ & $\begin{array}{c}\text { Coefficient } \\
(\mathrm{t}- \\
\text { statistic) }\end{array}$ & $\begin{array}{c}\text { Coefficient } \\
(t- \\
\text { statistic) }\end{array}$ \\
\hline NIM & $\begin{array}{l}0.378 \\
(1.49)\end{array}$ & $\begin{array}{l}-0.563 \\
(-0.75)\end{array}$ & $\begin{array}{l}-1.520 \\
(-0.94)\end{array}$ & $\begin{array}{c}0.617^{\star \star \star} \\
(3.24)\end{array}$ & $\begin{array}{l}-0.058 \\
(-1.39)\end{array}$ & $\begin{array}{c}-1.594^{\star \star} \\
(-2.38)\end{array}$ & $\begin{array}{c}3.842^{\star} \\
(1.93)\end{array}$ & $\begin{array}{c}1.312^{\star \star \star} \\
(6.25)\end{array}$ \\
\hline $\mathrm{NII}$ & $\begin{array}{l}0.008 \\
(0.53)\end{array}$ & $\begin{array}{l}-0.107 \\
(-0.78)\end{array}$ & $\begin{array}{l}-0.491 \\
(-1.25)\end{array}$ & $\begin{array}{c}0.155^{\star \star} \\
(2.22)\end{array}$ & $\begin{array}{l}-0.009 \\
(-1.07)\end{array}$ & $\begin{array}{c}0.322^{\star \star} \\
(2.22)\end{array}$ & $\begin{array}{l}-0.029 \\
(-0.58)\end{array}$ & $\begin{array}{l}0.071 \\
(1.24)\end{array}$ \\
\hline $\mathrm{Cl}$ & $\begin{array}{l}-0.005 \\
(-0.44)\end{array}$ & $\begin{array}{l}0.108 \\
(0.74)\end{array}$ & $\begin{array}{l}0.725 \\
(1.55)\end{array}$ & $\begin{array}{l}0.034 \\
(0.52)\end{array}$ & $\begin{array}{c}0.028^{\star \star \star} \\
(4.48)\end{array}$ & $\begin{array}{l}0.159 \\
(1.56)\end{array}$ & $\begin{array}{l}0.033 \\
(0.10)\end{array}$ & $\begin{array}{l}0.063^{*} \\
(1.87)\end{array}$ \\
\hline CAR & $\begin{array}{l}0.033^{*} \\
(1.99)\end{array}$ & $\begin{array}{l}0.216 \\
(0.84)\end{array}$ & $\begin{array}{c}2.125^{\star \star \star} \\
(3.19)\end{array}$ & $\begin{array}{c}0.261^{\star \star \star} \\
(3.70)\end{array}$ & $\begin{array}{l}0.014 \\
(1.18)\end{array}$ & $\begin{array}{c}0.101 \\
(0.59)\end{array}$ & $\begin{array}{c}-2.457^{\star \star \star} \\
(-4.43)\end{array}$ & $\begin{array}{c}0.279^{\star \star \star} \\
(-3.63)\end{array}$ \\
\hline LERNER & $\begin{array}{l}0.510 \\
(0.47)\end{array}$ & $\begin{array}{l}1.109 \\
(0.07)\end{array}$ & $\begin{array}{l}-26.779 \\
(-0.49)\end{array}$ & $\begin{array}{l}-1.828 \\
(-0.44)\end{array}$ & $\begin{array}{l}2.115^{\star \star} \\
(2.64)\end{array}$ & $\begin{array}{c}-37.65^{\star \star \star} \\
(3.57)\end{array}$ & $\begin{array}{l}-2.472 \\
(-0.06)\end{array}$ & $\begin{array}{l}-5.555 \\
(-1.26)\end{array}$ \\
\hline $\mathrm{BCON}$ & $\begin{array}{l}-0.011^{\star} \\
(-1.86)\end{array}$ & $\begin{array}{l}0.219^{\star \star} \\
(2.37)\end{array}$ & $\begin{array}{l}0.314 \\
(1.60)\end{array}$ & $\begin{array}{l}0.002 \\
(0.09)\end{array}$ & $\begin{array}{l}0.004 \\
(0.82)\end{array}$ & $\begin{array}{c}-0.141^{\star \star} \\
(-2.54)\end{array}$ & $\begin{array}{c}0.708^{\star \star} \\
(2.26)\end{array}$ & $\begin{array}{l}0.073^{*} \\
(1.99)\end{array}$ \\
\hline FGN & $\begin{array}{c}0.010^{\star \star \star} \\
(3.76)\end{array}$ & $\begin{array}{l}0.103 \\
(1.12)\end{array}$ & $\begin{array}{c}0.443^{*} \\
(1.98)\end{array}$ & $\begin{array}{c}-0.111^{\star \star \star} \\
(-3.96)\end{array}$ & $\begin{array}{l}-0.006 \\
(-1.44)\end{array}$ & $\begin{array}{l}-0.067 \\
(-1.14)\end{array}$ & $\begin{array}{l}0.199 \\
(1.12)\end{array}$ & $\begin{array}{l}-0.001 \\
(-0.04)\end{array}$ \\
\hline SIZE & $\begin{array}{c}0.040^{\star \star \star} \\
(5.24)\end{array}$ & $\begin{array}{l}0.219^{\star \star} \\
(2.05)\end{array}$ & $\begin{array}{l}-0.006 \\
(-0.01)\end{array}$ & $\begin{array}{l}0.111^{\star \star \star} \\
(4.35)\end{array}$ & $\begin{array}{c}0.012^{\star \star \star} \\
(2.90)\end{array}$ & $\begin{array}{l}-0.141^{\star *} \\
(-2.26)\end{array}$ & $\begin{array}{l}0.531^{*} \\
(1.94)\end{array}$ & $\begin{array}{c}0.179^{\star \star \star} \\
(6.07)\end{array}$ \\
\hline INF & $\begin{array}{l}0.0001 \\
(0.01)\end{array}$ & $\begin{array}{l}-0.260 \\
(-0.75)\end{array}$ & $\begin{array}{l}-0.758 \\
(-0.65)\end{array}$ & $\begin{array}{c}0.120^{\star} \\
(1.71)\end{array}$ & $\begin{array}{l}0.001 \\
(0.03)\end{array}$ & $\begin{array}{l}-0.271 \\
(-1.60)\end{array}$ & $\begin{array}{c}-0.003 \\
(-0.003)\end{array}$ & $\begin{array}{c}-0.163^{\star} \\
(-1.79)\end{array}$ \\
\hline$\Delta \mathrm{GDP}$ & $\begin{array}{l}-0.012 \\
(-0.52)\end{array}$ & $\begin{array}{l}-0.341 \\
(-1.48)\end{array}$ & $\begin{array}{c}1.574^{\star \star \star} \\
(3.97)\end{array}$ & $\begin{array}{l}0.017 \\
(0.27)\end{array}$ & $\begin{array}{l}0.022 \\
(0.87)\end{array}$ & $\begin{array}{l}0.357 \\
(1.31)\end{array}$ & $\begin{array}{c}2.256^{*} \\
(1.73)\end{array}$ & $\begin{array}{l}0.017 \\
(0.92)\end{array}$ \\
\hline UNEMP & $\begin{array}{c}0.053^{\star \star \star} \\
(3.05)\end{array}$ & $\begin{array}{c}-1.255^{\star \star \star} \\
(-4.37)\end{array}$ & $\begin{array}{l}-0.792 \\
(-1.03)\end{array}$ & $\begin{array}{l}-0.034 \\
(-0.55)\end{array}$ & $\begin{array}{l}-0.006 \\
(-0.39)\end{array}$ & $\begin{array}{l}0.123 \\
(1.08)\end{array}$ & $\begin{array}{l}0.628 \\
(0.84)\end{array}$ & $\begin{array}{c}-0.233^{\star \star \star} \\
(-3.16)\end{array}$ \\
\hline $\mathrm{RQ}$ & $\begin{array}{l}-0.801^{*} \\
(-1.66)\end{array}$ & $\begin{array}{l}-8.455 \\
(-1.00)\end{array}$ & $\begin{array}{l}-7.995 \\
(-0.29)\end{array}$ & $\begin{array}{c}-8.356^{\star \star \star} \\
(-4.76)\end{array}$ & $\begin{array}{l}-0.346 \\
(-0.99)\end{array}$ & $\begin{array}{l}3.269 \\
(0.77)\end{array}$ & $\begin{array}{c}-41.810^{\star \star} \\
(-2.41)\end{array}$ & $\begin{array}{c}-9.888^{\star \star \star} \\
(-5.12)\end{array}$ \\
\hline GT & $\begin{array}{l}-0.049 \\
(-0.12)\end{array}$ & $\begin{array}{c}16.863^{\star \star} \\
(2.68)\end{array}$ & $\begin{array}{l}12.352 \\
(0.66)\end{array}$ & $\begin{array}{l}0.547 \\
(0.30)\end{array}$ & $\begin{array}{c}0.677^{\star} \\
(1.91)\end{array}$ & $\begin{array}{c}-23.10^{\star \star \star} \\
(-4.18)\end{array}$ & $\begin{array}{c}-5.411^{\star \star \star} \\
(-3.27)\end{array}$ & $\begin{array}{l}2.392 \\
(1.22)\end{array}$ \\
\hline PS & $\begin{array}{l}-0.213 \\
(-0.96)\end{array}$ & $\begin{array}{c}-4.958^{\star \star} \\
(-2.17)\end{array}$ & $\begin{array}{l}-1.421 \\
(-0.22)\end{array}$ & $\begin{array}{l}1.040 \\
(1.19)\end{array}$ & $\begin{array}{c}-0.514^{\star \star \star} \\
(-3.39)\end{array}$ & $\begin{array}{l}-2.818 \\
(-1.57)\end{array}$ & $\begin{array}{l}-0.268 \\
(-0.03)\end{array}$ & $\begin{array}{c}-2.587^{\star \star \star} \\
(-2.78)\end{array}$ \\
\hline LEGAL & $\begin{array}{l}-0.032 \\
(-0.06)\end{array}$ & $\begin{array}{c}-24.943^{\star \star} \\
(-2.21)\end{array}$ & $\begin{array}{l}-18.323 \\
(-0.92)\end{array}$ & $\begin{array}{l}4.580 \\
(1.56)\end{array}$ & $\begin{array}{l}0.471 \\
(1.06)\end{array}$ & $\begin{array}{c}-11.525^{\star \star} \\
(-2.22)\end{array}$ & $\begin{array}{c}5.982^{\star \star \star} \\
(3.08)\end{array}$ & $\begin{array}{c}8.170^{\star \star \star} \\
(2.75)\end{array}$ \\
\hline $\mathrm{COC}$ & $\begin{array}{c}0.606 \\
(1.3)\end{array}$ & $\begin{array}{l}3.437 \\
(0.42)\end{array}$ & $\begin{array}{l}9.183 \\
(0.92)\end{array}$ & $\begin{array}{c}4.643^{\star \star} \\
(2.03)\end{array}$ & $\begin{array}{c}-0.569^{\star \star \star} \\
(-2.99)\end{array}$ & $\begin{array}{c}9.766^{\star \star \star} \\
(3.99)\end{array}$ & $\begin{array}{l}6.813 \\
(0.85)\end{array}$ & $\begin{array}{l}0.243 \\
(0.18)\end{array}$ \\
\hline Adjusted R2 & 46.76 & 62.26 & 25.14 & 62.52 & 61.31 & 59.88 & 58.96 & 62.52 \\
\hline Observations & 62 & 59 & 43 & 62 & 65 & 65 & 64 & 65 \\
\hline
\end{tabular}


Ozili P.K. (2018). Banking Stability Determinants in Africa. Forthcoming in: International Journal of Managerial Finance, Vol 14.

\begin{tabular}{|c|c|c|c|c|}
\hline \multicolumn{5}{|c|}{ Table 4: Additional Analyses } \\
\hline \multicolumn{5}{|c|}{ During-Crisis Banking Stability Determinants } \\
\hline \multicolumn{5}{|c|}{$\begin{array}{l}\text { Table } 3 \text { Column } 1-4 \text { show the OLS regression results. In all estimations, standard } \\
\text { errors are clustered by country and year. }\end{array}$} \\
\hline & BS: InZscore & BS: NPL & BS: LLC & BS: SDFD \\
\hline & (1) & (2) & (3) & (4) \\
\hline & $\begin{array}{l}\text { Coefficient } \\
\text { (t-statistic) }\end{array}$ & $\begin{array}{l}\text { Coefficient } \\
\text { (t-statistic) }\end{array}$ & $\begin{array}{l}\text { Coefficient } \\
\text { (t-statistic) }\end{array}$ & $\begin{array}{l}\text { Coefficient } \\
\text { (t-statistic) }\end{array}$ \\
\hline NIM & $\begin{array}{l}-0.062^{*} \\
(-1.87)\end{array}$ & $\begin{array}{l}-0.694 \\
(-1.22)\end{array}$ & $\begin{array}{l}4.586 \\
(1.16)\end{array}$ & $\begin{array}{c}0.616^{\star \star \star} \\
(3.24)\end{array}$ \\
\hline NII & $\begin{array}{l}-0.002 \\
(-0.41) \\
\end{array}$ & $\begin{array}{l}-0.205 \\
(-1.44) \\
\end{array}$ & $\begin{array}{l}-0.747 \\
(-0.82) \\
\end{array}$ & $\begin{array}{l}0.155^{\star \star} \\
(2.22)\end{array}$ \\
\hline $\mathrm{Cl}$ & $\begin{array}{l}0.022^{\star \star} \\
(2.63)\end{array}$ & $\begin{array}{c}0.520^{\star \star \star} \\
(3.67)\end{array}$ & $\begin{array}{l}0.867^{\star} \\
(1.99)\end{array}$ & $\begin{array}{l}0.034 \\
(0.52)\end{array}$ \\
\hline CAR & $\begin{array}{c}0.044^{\star \star \star} \\
(3.35)\end{array}$ & $\begin{array}{l}-0.247 \\
(-0.91)\end{array}$ & $\begin{array}{l}0.494 \\
(0.47)\end{array}$ & $\begin{array}{c}0.261^{\star \star \star} \\
(3.70)\end{array}$ \\
\hline LERNER & $\begin{array}{l}0.503 \\
(0.62)\end{array}$ & $\begin{array}{l}-17.49 \\
(-1.34)\end{array}$ & $\begin{array}{c}-66.29^{*} \\
(-1.67)\end{array}$ & $\begin{array}{l}-1.828 \\
(-0.44)\end{array}$ \\
\hline $\mathrm{BCON}$ & $\begin{array}{l}-0.013^{*} \\
(-1.90)\end{array}$ & $\begin{array}{l}-0.110 \\
(-0.97)\end{array}$ & $\begin{array}{l}-0.278 \\
(-0.68)\end{array}$ & $\begin{array}{l}0.002 \\
(0.09)\end{array}$ \\
\hline FGN & $\begin{array}{l}0.005 \\
(0.94) \\
\end{array}$ & $\begin{array}{l}0.132^{\star} \\
(1.81)\end{array}$ & $\begin{array}{l}-0.042 \\
(-0.12) \\
\end{array}$ & $\begin{array}{c}-0.090^{\star \star \star} \\
(-3.10)\end{array}$ \\
\hline SIZE & $\begin{array}{l}0.005 \\
(0.94)\end{array}$ & $\begin{array}{c}0.146^{*} \\
(1.81)\end{array}$ & $\begin{array}{l}0.469 \\
(1.11)\end{array}$ & $\begin{array}{l}0.111^{\star \star \star} \\
(4.35)\end{array}$ \\
\hline INF & $\begin{array}{l}0.001 \\
(0.15)\end{array}$ & $\begin{array}{c}0.100 \\
(0.38)\end{array}$ & $\begin{array}{c}1.669^{\star \star} \\
(2.17)\end{array}$ & $\begin{array}{c}0.120^{\star} \\
(1.71)\end{array}$ \\
\hline$\Delta \mathrm{GDP}$ & $\begin{array}{l}0.034 \\
(1.37)\end{array}$ & $\begin{array}{l}-1.116^{\star \star} \\
(-2.09)\end{array}$ & $\begin{array}{l}-0.686 \\
(-0.22)\end{array}$ & $\begin{array}{l}0.017 \\
(0.27)\end{array}$ \\
\hline UNEMP & $\begin{array}{c}0.062^{\star \star \star} \\
(4.08)\end{array}$ & $\begin{array}{l}-0.203 \\
(-0.80)\end{array}$ & $\begin{array}{l}0.999 \\
(0.56)\end{array}$ & $\begin{array}{l}-0.034 \\
(-0.55)\end{array}$ \\
\hline$R Q$ & $\begin{array}{c}-0.141 \\
(-0.44)\end{array}$ & $\begin{array}{c}-15.89^{\star \star \star} \\
(-3.85)\end{array}$ & $\begin{array}{c}-99.96^{\star \star \star} \\
(-4.10)\end{array}$ & $\begin{array}{c}-8.357^{\star \star \star} \\
(-4.76)\end{array}$ \\
\hline GT & $\begin{array}{l}0.043 \\
(0.11)\end{array}$ & $\begin{array}{l}-6.404 \\
(-1.04)\end{array}$ & $\begin{array}{l}22.42 \\
(0.79)\end{array}$ & $\begin{array}{l}0.547 \\
(0.30)\end{array}$ \\
\hline PS & $\begin{array}{c}-1.326^{\star \star \star} \\
(-5.35)\end{array}$ & $\begin{array}{l}-5.265 \\
(-1.01) \\
\end{array}$ & $\begin{array}{l}-21.25 \\
(-1.14) \\
\end{array}$ & $\begin{array}{l}1.040 \\
(1.19) \\
\end{array}$ \\
\hline LEGAL & $\begin{array}{l}1.087^{\star \star} \\
(2.49)\end{array}$ & $\begin{array}{l}-2.429 \\
(-0.31)\end{array}$ & $\begin{array}{c}103.69^{\star \star \star} \\
(5.23)\end{array}$ & $\begin{array}{l}4.580 \\
(1.56)\end{array}$ \\
\hline $\mathrm{COC}$ & $\begin{array}{l}0.418 \\
(0.96)\end{array}$ & $\begin{array}{l}3.977 \\
(0.59)\end{array}$ & $\begin{array}{l}-16.28 \\
(-1.03)\end{array}$ & $\begin{array}{c}4.643^{\star *} \\
(2.03)\end{array}$ \\
\hline Adjusted R & 80.03 & 54.89 & 34.41 & 62.52 \\
\hline F-statistic & & & & \\
\hline$p$-value & & & & \\
\hline Observations & 36 & 35 & 30 & 62 \\
\hline
\end{tabular}


Ozili P.K. (2018). Banking Stability Determinants in Africa. Forthcoming in: International Journal of Managerial Finance, Vol 14.

Appendix

Table A1: Variable definitions and data sources

The table shows the definition of the variables used in the paper and the data sources

\begin{tabular}{|c|c|c|}
\hline Name & Definition & Source \\
\hline SDFD & $\begin{array}{l}\text { The standard deviation of the ratio of private credit of deposit } \\
\text { money banks to GDP. }\end{array}$ & $\begin{array}{l}\text { Global Financial Development } \\
\text { Database }\end{array}$ \\
\hline INF & Inflation, consumer prices (annual \%) & World Bank \\
\hline UNEMP & Unemployment, total (\% of total labor force) & $\begin{array}{l}\text { ILO estimates, archived in } \\
\text { World Bank }\end{array}$ \\
\hline GDP & Real gross domestic product growth rate (\%) & World Bank \\
\hline LERNER & $\begin{array}{l}\text { The Lerner index is defined as the difference between output } \\
\text { prices and marginal costs (relative to prices). Lerner index is } \\
\text { widely used as an indicator of the degree of market power for } \\
\text { the banking sector (Beck et al., 2013). }\end{array}$ & $\begin{array}{l}\text { Global Financial Development } \\
\text { Database. World Bank }\end{array}$ \\
\hline $\mathrm{BCON}$ & $\begin{array}{l}\text { Banking concentration is defined as the ratio of the assets of } \\
\text { the three largest commercial banks to total commercial } \\
\text { banking assets in a country. }\end{array}$ & $\begin{array}{l}\text { Global Financial Development } \\
\text { Database. World Bank }\end{array}$ \\
\hline SIZE & $\begin{array}{l}\text { Private credit by deposit money banks and other financial } \\
\text { institutions to GDP }\end{array}$ & $\begin{array}{l}\text { Global Financial Development } \\
\text { Database. World Bank }\end{array}$ \\
\hline FGN & $\begin{array}{l}\text { Percentage of the number of foreign owned banks to the } \\
\text { number of the total banks in an economy. }\end{array}$ & $\begin{array}{l}\text { Global Financial Development } \\
\text { Database. World Bank }\end{array}$ \\
\hline NIM & Net interest margin ratio & $\begin{array}{l}\text { Global Financial Development } \\
\text { Database. World Bank }\end{array}$ \\
\hline $\mathrm{NII}$ & Bank noninterest income to total income (\%) & $\begin{array}{l}\text { Global Financial Development } \\
\text { Database. World Bank }\end{array}$ \\
\hline $\mathrm{Cl}$ & Bank cost to income ratio (\%) & $\begin{array}{l}\text { Global Financial Development } \\
\text { Database. World Bank }\end{array}$ \\
\hline CAR & Bank regulatory capital to risk-weighted assets (\%) & $\begin{array}{l}\text { Global Financial Development } \\
\text { Database. World Bank }\end{array}$ \\
\hline$R Q$ & $\begin{array}{l}\text { Regulatory Quality captures perceptions of the ability of the } \\
\text { government to formulate and implement sound policies and } \\
\text { regulations that permit and promote private sector } \\
\text { development. } R Q \text { ranges from }-2.5 \text { to } 2.5 \text {, and higher values } \\
\text { indicate higher regulatory effectiveness }\end{array}$ & $\begin{array}{l}\text { The World Governance } \\
\text { Indicator Database. World } \\
\text { Bank }\end{array}$ \\
\hline GT & $\begin{array}{l}\text { Government Effectiveness captures perceptions of the quality } \\
\text { of public services, the quality of the civil service and the } \\
\text { degree of its independence from political pressures, the } \\
\text { quality of policy formulation and implementation, and the } \\
\text { credibility of the government's commitment to such policies. } \\
\text { GT ranges from }-2.5 \text { to } 2.5 \text {, and higher values indicate higher } \\
\text { government effectiveness }\end{array}$ & $\begin{array}{l}\text { The World Governance } \\
\text { Indicator Database. World } \\
\text { Bank }\end{array}$ \\
\hline PS & $\begin{array}{l}\text { Political Stability and Absence of Violence/Terrorism } \\
\text { measures perceptions of the likelihood of political instability } \\
\text { and/or politically-motivated violence, including terrorism. PS } \\
\text { ranges from }-2.5 \text { to } 2.5 \text {. The higher the better }\end{array}$ & $\begin{array}{l}\text { The World Governance } \\
\text { Indicator Database. World } \\
\text { Bank }\end{array}$ \\
\hline $\mathrm{COC}$ & $\begin{array}{l}\text { Control of Corruption captures perceptions of the extent to } \\
\text { which public power is exercised for private gain. COC ranges } \\
\text { from }-2.5 \text { to } 2.5 \text {, and higher values indicate higher corruption } \\
\text { control }\end{array}$ & $\begin{array}{l}\text { The World Governance } \\
\text { Indicator Database. World } \\
\text { Bank }\end{array}$ \\
\hline LEGAL & $\begin{array}{l}\text { The rule of law index. Higher values indicate higher efficiency } \\
\text { in law enforcement. }\end{array}$ & $\begin{array}{l}\text { The World Governance } \\
\text { Indicator Database. World } \\
\text { Bank }\end{array}$ \\
\hline NPL & $\begin{array}{l}\text { The ratio of non-performing loans (payment of interest and } \\
\text { principal past due date by } 90 \text { days or more) to total gross } \\
\text { loans }\end{array}$ & $\begin{array}{l}\text { Global Financial Development } \\
\text { Database. World Bank and } \\
\text { BankScope }\end{array}$ \\
\hline LLC & $\begin{array}{l}\text { The ratio of loan loss provisions to total non-performing } \\
\text { loans over each }\end{array}$ & $\begin{array}{l}\text { Global Financial Development } \\
\text { Database. World Bank. }\end{array}$ \\
\hline LnZSCORE & $\begin{array}{l}\text { This captures the probability of default of a country's banking } \\
\text { system. Z-score compares the buffer of a country's banking } \\
\text { system (capitalization and returns) with the volatility of such } \\
\text { returns. }\end{array}$ & $\begin{array}{l}\text { Global Financial Development } \\
\text { Database. World Bank and } \\
\text { BankScope }\end{array}$ \\
\hline
\end{tabular}


Ozili P.K. (2018). Banking Stability Determinants in Africa. Forthcoming in: International Journal of Managerial Finance, Vol 14.

\begin{tabular}{|c|c|c|c|c|c|c|c|c|c|c|c|c|c|c|c|c|c|c|c|c|}
\hline \multicolumn{21}{|c|}{ A2: Descriptive statistics. Country-level information } \\
\hline & $\mathrm{BCON}$ & CAR & $\mathrm{Cl}$ & $\operatorname{coc}$ & SIZE & FGN & GDP & GT & $\begin{array}{c}\text { IN } \\
\text { F }\end{array}$ & $\begin{array}{c}\mathrm{LE} \\
\mathrm{GA} \\
\mathrm{L}\end{array}$ & $\begin{array}{l}\text { LER } \\
\text { NER }\end{array}$ & $\begin{array}{c}\text { LnZSC } \\
\text { ORE }\end{array}$ & $\mathrm{NII}$ & $\begin{array}{l}\mathrm{NI} \\
\mathrm{M}\end{array}$ & $\begin{array}{c}\mathrm{NP} \\
\mathrm{L}\end{array}$ & $\begin{array}{l}\mathrm{LL} \\
\mathrm{C}\end{array}$ & PS & $\mathrm{RQ}$ & SDFD & UNEMP \\
\hline Mean & 76.8 & 17.4 & 61.5 & -0.5 & 25.6 & 47 & 5.1 & $\begin{array}{c}- \\
0.68\end{array}$ & $\begin{array}{l}45 \\
.2\end{array}$ & $\begin{array}{c}- \\
0.6 \\
7\end{array}$ & 0.28 & 2.22 & $\begin{array}{l}41 . \\
12\end{array}$ & $\begin{array}{c}6 . \\
63\end{array}$ & $\begin{array}{l}11 . \\
22\end{array}$ & $\begin{array}{l}63 \\
.9\end{array}$ & $\begin{array}{c}- \\
0.5\end{array}$ & -0.6 & 15.3 & 10.4 \\
\hline Median & 79.6 & 16.3 & 59.1 & -0.6 & 17.9 & 50 & 4.6 & -0.72 & $\begin{array}{c}5 . \\
65\end{array}$ & $\begin{array}{c}- \\
0.6 \\
8\end{array}$ & 0.29 & 2.27 & $\begin{array}{l}41 . \\
9\end{array}$ & $\begin{array}{c}6 . \\
02\end{array}$ & $\begin{array}{r}8 . \\
40\end{array}$ & 60 & $\begin{array}{c} \\
0.3\end{array}$ & -0.5 & 17.3 & 7.2 \\
\hline Max & 100.0 & $\begin{array}{c}43.4 \\
0\end{array}$ & 218.1 & 1.2 & 97.8 & 100 & 149 & 1.04 & $\begin{array}{c}24 \\
411 \\
.0\end{array}$ & $\begin{array}{c}1.0 \\
6\end{array}$ & 0.64 & 4.54 & $\begin{array}{l}93 \\
.2\end{array}$ & $\begin{array}{l}39 \\
.2\end{array}$ & $\begin{array}{c}74 \\
.1\end{array}$ & $\begin{array}{c}19 \\
3\end{array}$ & 1.1 & 1.1 & 20.1 & 39.3 \\
\hline Min & 22.3 & 1.75 & 20.0 & -2.1 & 1.69 & 0.0 & $\begin{array}{c}- \\
62.07\end{array}$ & -1.9 & $\begin{array}{c} \\
35 . \\
8\end{array}$ & $\begin{array}{c}- \\
2.2 \\
2\end{array}$ & -1.32 & -0.40 & $\begin{array}{c}1.4 \\
3\end{array}$ & $\begin{array}{c}0 . \\
03\end{array}$ & $\begin{array}{c}0 . \\
96\end{array}$ & $\begin{array}{c}1.8 \\
0\end{array}$ & $\overline{-}$ & -2.4 & 1.06 & 0.56 \\
\hline Std. Dev. & 18.7 & 6.26 & 22.9 & 0.6 & 20.1 & 26 & 8.52 & 0.6 & $\begin{array}{r}82 \\
5.9\end{array}$ & $\begin{array}{c}0 . \\
64 \\
\end{array}$ & 0.19 & 0.65 & $\begin{array}{c}16 . \\
5\end{array}$ & $\begin{array}{r}3 . \\
73 \\
\end{array}$ & $\begin{array}{r}9 . \\
56\end{array}$ & $\begin{array}{l}26 \\
.8\end{array}$ & $\begin{array}{l}0 . \\
9\end{array}$ & 0.6 & 3.97 & 7.7 \\
\hline Obs & 660 & 314 & 836 & 958 & 883 & 626 & 943 & 958 & $\begin{array}{c}90 \\
1\end{array}$ & $\begin{array}{l}96 \\
0\end{array}$ & 542 & 857 & $\begin{array}{l}83 \\
2\end{array}$ & $\begin{array}{l}80 \\
4\end{array}$ & $\begin{array}{l}31 \\
4\end{array}$ & $\begin{array}{c}28 \\
0\end{array}$ & $\begin{array}{c}96 \\
0\end{array}$ & 960 & 958 & 940 \\
\hline
\end{tabular}

